Article

\title{
Between Abundance and Constraints: The Natural Resource Equation of Asia's Diverging, Higher-Income City Models
}

\author{
Philipp Rode ${ }^{1, *(\mathbb{D}}$, Alexandra Gomes ${ }^{1}{ }^{\mathbb{C}}$, Muhammad Adeel ${ }^{2}$, Fizzah Sajjad ${ }^{1}$, Andreas Koch ${ }^{3}$ \\ and Syed Monjur Murshed ${ }^{3}(\mathbb{D}$ \\ 1 LSE Cities, London School of Economics and Political Science, Houghton Street, London WC2A 2AE, UK; \\ a.peca-amaral-gomes@lse.ac.uk (A.G.); f.sajjad@lse.ac.uk (F.S.) \\ 2 Institute of Transport Studies, University of Leeds, Leeds LS29JT, UK; m.adeel@leeds.ac.uk \\ 3 European Institute for Energy Research, Karlsruhe Institute of Technology, 76131 Karlsruhe, Germany; \\ andreas.koch@eifer.uni-karlsruhe.de (A.K.); monjur.murshed@eifer.uni-karlsruhe.de (S.M.M.) \\ * Correspondence: P.Rode@lse.ac.uk
}

Received: 8 October 2020; Accepted: 27 October 2020; Published: 31 October 2020

\begin{abstract}
This paper investigates how natural resource conditions impact the physical development of cities and how, once built, the urban spatial structure leads to different patterns of resource use. The point of departure for this research is the common "resource urbanisms" assumption that cities are directly affected by the availability and costs of natural resources, and that in turn, different urbanisms result in substantial differences in resource use and consequent impact on the environment. Considering extreme and divergent, higher-income urban models of Kuwait, Abu Dhabi, Hong Kong and Singapore, the paper focusses on two resources, land and energy, and the case of building cooling and transport energy demand. The research uses a mixed methods approach which includes qualitative methods such as expert interviews, analysis of planning documents and historic planning decisions, alongside quantitative methods such as remote sensing, GIS and data analysis and energy modelling. The paper suggests that land availability is a major driver of urban form while energy prices may play a secondary role. It also finds that urban form-induced energy efficiencies for transport and cooling energy diverge in the four cities by a factor of five and two, respectively.
\end{abstract}

Keywords: urbanism; urban form; building typology; transport; infrastructure; cooling energy; Kuwait; Abu Dhabi; Hong Kong; Singapore

\section{Introduction}

Advancing our understanding of global urbanisation and urban change increasingly involves making better connections with related resource conditions, resource use and environmental sustainability [1-6]. Beyond the exploration of broader notions of planetary urbanization [7,8], analyzing the development and performance of individual cities remains an important point of departure for developing the desired evidence base and informing new conceptual frameworks. Cities are commonly understood as complex systems-of-systems [9-11] which incorporate infrastructure systems and sub-systems that have an interconnected and co-constitutive character [12]. To address this complexity pragmatically, empirical research tends to isolate urban subsystems to allow for a more robust and bounded study of causal relationships.

At the same time, and as part of a broader socio-spatial lens which underpins many strands of urban studies and science, considerable attention has been given to a more comprehensive study of urban form [13-19] and its effects in aggregate terms. A broad understanding of urban form is the "spatial configuration of fixed elements within a metropolitan region" [20]. Urban form is multi-scalar 
and includes characteristics at the metropolitan, city and neighbourhood scale [21,22]. As part of their review of urban form impacts on energy consumption, Silva et al. [17] identify the following 14 urban form attributes: density, diversity (mix of urban functions), green areas, compactness (clustering of built structures), passivity (building zones naturally lit, ventilated and heated/cooled), shading, orientation, connectivity, accessibility, distance to central business district, proximity to public transport, design (low-scale features of the urban environment) and hierarchy of street network.

For this introduction, we review below both research dedicated to how resource conditions have shaped cities and how urban form evolves as well as how urban form impacts resource use and environmental sustainability. What is rare in the reviewed academic literature is that these two perspectives are brought together. This is surprising in so far as urban-related sectoral, modelling-based and policy-oriented work naturally operates with a logic model and its continuum of inputs-outputs-outcomes-impact [23]. This is evident in transport studies investigating how new taxes (inputs) affect fuel prices (outputs), in turn changing travel behavior (outcomes) and resulting in changes in carbon emissions (impact) [24,25]. It is also evident in building research interested in green construction. Here, limited access to cheap oil or gas (inputs) has increased costs for conventional heating (outputs) which led to better insulation standards (outcomes) and again lower carbon emissions (impact) $[26,27]$.

While the application of such basic logic models are well understood at the scale of socio-technical subsystems, their application to what we consider here as "resource urbanisms"- the broader context of the development of urban land, natural resource conditions and resource implications at the metropolitan and city design scales-is less common. Furthermore, while it is broadly understood that resource conditions shape urban development, a more specific analysis of different resource factors and their impact on components of urban form is less prominent as part of the academic literature. By contrast, considerable attention of prior research has been given to the analysis of resource and energy implications of different urban forms. ${ }^{1}$ Both research fields are briefly reviewed in the following subsections.

\subsection{Resource Conditions as Determinants of Urban Form}

The availability of natural resources is frequently used to understand city formation, while the costs of natural resources, primarily of land and energy, are seen to play an important role in shaping city growth and urban development [28-31]. As Freeman [32] suggests, "resources are the cornerstone of urban development" and many cities have developed around resources such as water, minerals, oil and gas. Countries with scarce natural resources have depended on trade to meet basic needs and, increasingly in the twentieth century, have relied on industrialisation and the development of a competitive service sector to achieve economic growth and urbanisation. As a result, scholarship on urbanisation in resource-poor cities and countries, particularly in the East Asian context, has focused on economic development and industrialisation to explain changes in urban development patterns [33,34].

Cities are also shaped by resource abundance and recent research shows that urbanisation itself is also directly correlated with resource exports. Using a sample of 116 developing nations between 1960 and 2010, Gollin, Jedwab and Vollrath [35] argue that while urbanisation has traditionally been linked to industrialisation [36,37] and economic growth [38-42], it can also be explained through resource exports. In support of this claim, they show that countries that are dependent on natural resource exports are just as likely to experience a high rate of urbanisation as those that depend on manufacturing. Yet, they point out that the nature of urbanisation differs depending on a country's economic base. Urbanisation in countries that are primarily dependent on resource exports (such as Kuwait, Saudi Arabia and

1 We conducted a quantitative review of directly related terminology of academic research indexed in Web of Science and Google Scholar comparing combinations of "urban form" with terms either associated with resource conditions as determinants of urban form or resource implications as dependent variables of urban form (see Appendix A, Table A2). 
Nigeria) is concentrated in "consumption cities" where a large number of workers are employed in "non-tradable services such as commerce, transportation, personal, government services" [35]. In contrast, urbanisation in countries with strong industrial bases is concentrated in "production cities" where workers are largely employed in the manufacturing sector.

Other scholars suggest that in addition to the degree of dependence on resource exports, the nature of the state itself $[43,44]$, the type of "institutions governing land markets" and the system of property rights [45] are integral factors that influence resource use and urbanisation patterns across cities. Pistor and Schutter [46] further argue that "beyond instances of absolute scarcity, essential resources are scarce only in relative terms-they are human made and result from politics and institutional choices".

While the studies above focus on the broader socio-economic impact of resource conditions on urban development, they tend to not address specific impacts on settlement patterns and urban form. Within the latter context, a considerable amount of research analyses global urban land expansion but usually with less of an explicit empirical focus on its effects and consequences. Angel et al. [47] developed a dataset of over 3000 metropolitan cities and show that "urban land cover in developing countries will increase from $300,000 \mathrm{~km}^{2}$ in 2000 to $770,000 \mathrm{~km}^{2}$ in 2030 , and 1,200,000 $\mathrm{km}^{2}$ in 2050 ". Seto et al. [48] predict that urban land cover will increase even more rapidly by 2030: "between $430,000 \mathrm{~km}^{2}$ and 12,568,000 km², with an estimate of 1,527,000 $\mathrm{km}^{2}$ more likely", (p. 1). Their forecasts are based on a review of 181 papers that used remote sensing to assess urban land-use change between 1988 and 2008, and a number of other datasets.

The latter study is also a good example of identifying some relevant urban expansion drivers and suggesting priorities for future research. While changes in population and GDP impact urban land expansion, the authors suggest that it is critical to further assess how "international capital flows, the informal economy, land use policy and generalized transport costs" influence differences in urban expansion rates and patterns (p. 1), particularly as this is likely to permanently impact the environment. Similarly, through a study of 193 scientific articles, [49] find that the "population and income growth, increased transport accessibility, weak planning, and subsidies encouraging land consumption and automobile use" are some of the factors that contribute to urban land expansion.

In terms of resource conditions as drivers of urban form, the scarcity of land is a particularly critical one. For example, land-scarce economic policy is a fundamental driver of urban form in land-poor city states such as Hong Kong and Singapore. Trade relationships with the immediate hinterland beyond its borders allow Hong Kong to outsource industrial and manufacturing activities while developing a high-density, service-oriented economy [50]. However, and as argued by Addae Dapaah [51] for the case of Singapore, even in extreme cases of land constraints, there exists an underutilisation of land as a result of a considerable demand for lower-density housing.

More recently, an increasing number of scholars have studied the manifestations of oil-based development in an urban setting, particularly in cities of the Middle East and the Persian Gulf [52-60]. Using a historical lens, they focus on labour camps, new company towns and older "urban settlements" that served as key physical sites of oil-based development and modernity. Many argue that oil should not simply be understood as money and rent but as an agent that has "upset delicate environmental and ecological balances" [52], "fostered a desire of rapid modernization" [53], created "new geographies of consumption and leisure" [61] and "played a variety of roles in a city's political, economic, social affairs related to urban development" [54]. Other scholars have pointed to the environmental and fiscal risks of resource consumption in oil economies. Here, low energy prices and high incomes imply high consumption, which in turn leads to particular forms of urban development. A particularly relevant perspective for this paper is offered by Creutzig [31], modelling and identifying links between fuel price and urban form.

Finally, a mediating factor between broader resource conditions and urban expansion is urban infrastructure development and, above all, transport infrastructure, which has been the focus of some recent studies. Baum-Snow [62] shows for US metropolitan regions that each new highway constructed through an urban core resulted in a decrease in central city residents by 18 per cent. For Chinese cities' 
expansion, the construction of radial highways and ring roads resulted in a relocation of around 25 per cent of central city residents to surrounding regions $[63,64]$.

\subsection{Urban Form Impacting on Resource Consumption}

Studies have shown that urban areas consume between 67 and 76 per cent of the world's energy, mainly as a result of the concentration of affluent populations and energy-intense activities. These generate between 71 and 76 per cent of $\mathrm{CO}_{2}$ emissions [65]. A key issue with regard to urban sustainability relates to the physical shape of cities, their urban forms and infrastructures [3,6,17,66-68]. While individual urban form characteristics may only have marginal effects on the overall energy demand of cities, Ewing and Cervero [66] stress that the aggregate effect of urban form parameters may be significant. For example, it is widely suggested that a more compact and connected model of urban development may not only be more resource efficient, but ultimately more effective in harnessing the growth potential of cities as it facilitates efficient access to people, services, goods and ideas $[65,69,70]$.

Above all, residential and transport energy demands, which are predominantly urban, are centrally determined by the spatial characteristics of buildings and urban form $[17,31,67,71-76]$. They also represent major shares of global energy demand. In 2015, the residential sector constituted 22 per cent of global energy consumption [77]. Though still slightly lower than building energy use in absolute terms, transport energy demands are particularly relevant as they are growing rapidly. In 2014, transport's share of global energy demand was 28 per cent [77] and comprised nearly 65 per cent of total global oil consumption-almost 20 per cent more than in 1973 [78]. It also contributed to 22 per cent of the world's energy-related greenhouse gas emissions [65].

In the case of buildings, urban form or geometry, alongside behaviour, technology and building design, are considered key factors of heating/cooling energy demand $[68,79,80]$. Together, these factors may explain the up to twenty-fold difference in energy demand observed for temperature control in buildings $[67,79,80]$. The urban form and heating/cooling energy equation centrally considers questions of solar gains and temperature containment of building shapes. Most research suggests that solar gain is positively associated with lower building densities, while temperature containment is linked with higher building densities [67]. For the case of heating energy demand, Steemers [73] identifies a $22 \%$ increase in demand when comparing a 30 degree obstruction of a sun-oriented façade compared with an unobstructed case. Yannas [81] finds a 40\% lower heat energy demand of apartments compared with detached houses and suggested a floor-area ratio of 2.5 as optimal density for heat energy efficiency.

Vartholomaios [82] conducted a parametric study on the influence of urban form in the Mediterranean climate of Thessaloniki and found compactness to be one of the characteristics linked to low energy demand. Zhang et al. [83] investigated differences in urban block typology on solar potentials as well as on energy use intensity, and found that the latter can lead to up to a "twelve times higher rate of reduction in building cooling loads [ ... ] and $25 \%$ lower building net energy use intensity". In a comprehensive study on urban density and its impacts on energy use in buildings, Güneralp et al. [75] conclude that "urban density influences future energy use as much as energy efficiency". The modelled scenarios showed similar long-term savings for heating and cooling needs when comparing both separately.

Similarly, evidence on the relationship between urban form and transport intensity has been building up for decades [84,85]. Ewing et al. [86] identified a difference in transport intensity measured by vehicle miles travelled per capita between high- and low-density areas of more than $40 \%$ even when controlling for other factors. Research conducted by the US National Research Council (National Research Council 2009) associates the doubling of metropolitan densities while concentrating employment with up to 25 per cent reduction potentials of vehicle kilometres travelled (VKT).

High transport energy demand is strongly correlated with the levels of car use (as opposed to walking, cycling and public transport) and many studies have shown significantly higher levels of automobile dependence in areas of lower population and employment densities [87-90]. The multi-scalar dimensions of urban form also require a consideration of neighbourhood-level 
implications. At that level, Ewing and Cervero [66] show that density, land-use mix and street design have a significant impact on the likelihood of walking.

\subsection{Knowledge Gap and Study Aim}

As indicated in this brief literature review, there is considerable research interest in the relationship between cities, resource conditions and implications. While there is increasing evidence available on the relationships between resource dependence, urbanisation rates and standards of living, few studies explore patterns of urban development through a comparative lens, with the city as the unit of analysis. We also find a considerable imbalance between work focusing on how urban form impacts on resource consumption, which is the subject of numerous recent studies, and on how resource conditions impact urban form, which is covered far less frequently. Furthermore, no single study to our knowledge cuts across the "resource urbanisms" spectrum of resource conditions, urban form and resource implications.

A further bias of existing empirical works exists in relation to its regional focus. While there is a substantial body of comparative work that explores the relationship between urban development, infrastructure and land and/or resource use for cities in the United States and Europe [62,86,91-93], with the exception of emergent research on China [64,94,95], there are far fewer empirical and comparative insights on geographical areas where current urban growth is most pronounced, including affluent, emerging economy cities. Finally, there appear to be considerable opportunities to expand established research on heat energy demand in cities to a corresponding analysis on cooling energy demand, alongside questions on potential trade-offs between transport and cooling energy efficiency.

To address these knowledge gaps, this study aims, at a high level, to compare and analyse patterns of urban form (focusing on density, diversity, transport infrastructure and building composition) in "land- and energy-rich" Kuwait and Abu Dhabi, and by contrast, in Hong Kong and Singapore, which are more limited in terms of available land and cheap energy supply. We explore these urban form characteristics in relation to two resource conditions (land availability and energy costs), alongside resource consumption, through an assessment of building cooling and transport energy demand. This paper is guided by the common assumption that cities and urban development are directly affected by the availability and costs of natural resources and that, in turn, different forms of urban development result in substantial differences in resource use. The paper addresses three guiding research questions:

1. How do natural resource conditions impact the urban forms of cities, how does the resultant urban spatial structure lead to different patterns of resource use and which urban form characteristics mediate the relationship between resource constraints and consumption?

2. What are the variations in theoretical building cooling and transport energy demands resulting from different urban forms in the case study cities and to what degree are these aligned with actual empirical data on energy consumption in these cities?

3. For the selected higher-income case study cities, is it possible to identify a basic "resource urbanisms" logic whereby resource constraints ultimately lead to better environmental sustainability outcomes?

\section{Materials and Methods}

To address these guiding research questions, we employed the research framework illustrated in Figure 1 and the multi-method approach detailed below. Cutting across the four stages of (A) define and design, (B) collect and prepare, (C) analyse and (D) compare and conclude runs our two-fold interest in the "resource urbanisms" spectrum of resource conditions impacting on urban form (in green) and urban form impacting on energy consumption (in red). While the latter analysis relied exclusively on a quantitative analysis based on contemporary data, the first included time series data collection and analysis, and also relied on qualitative research methods. With a focus on the more prominent 
quantitative aspects of our research, the subsection below introduces the corresponding methods in more detail.

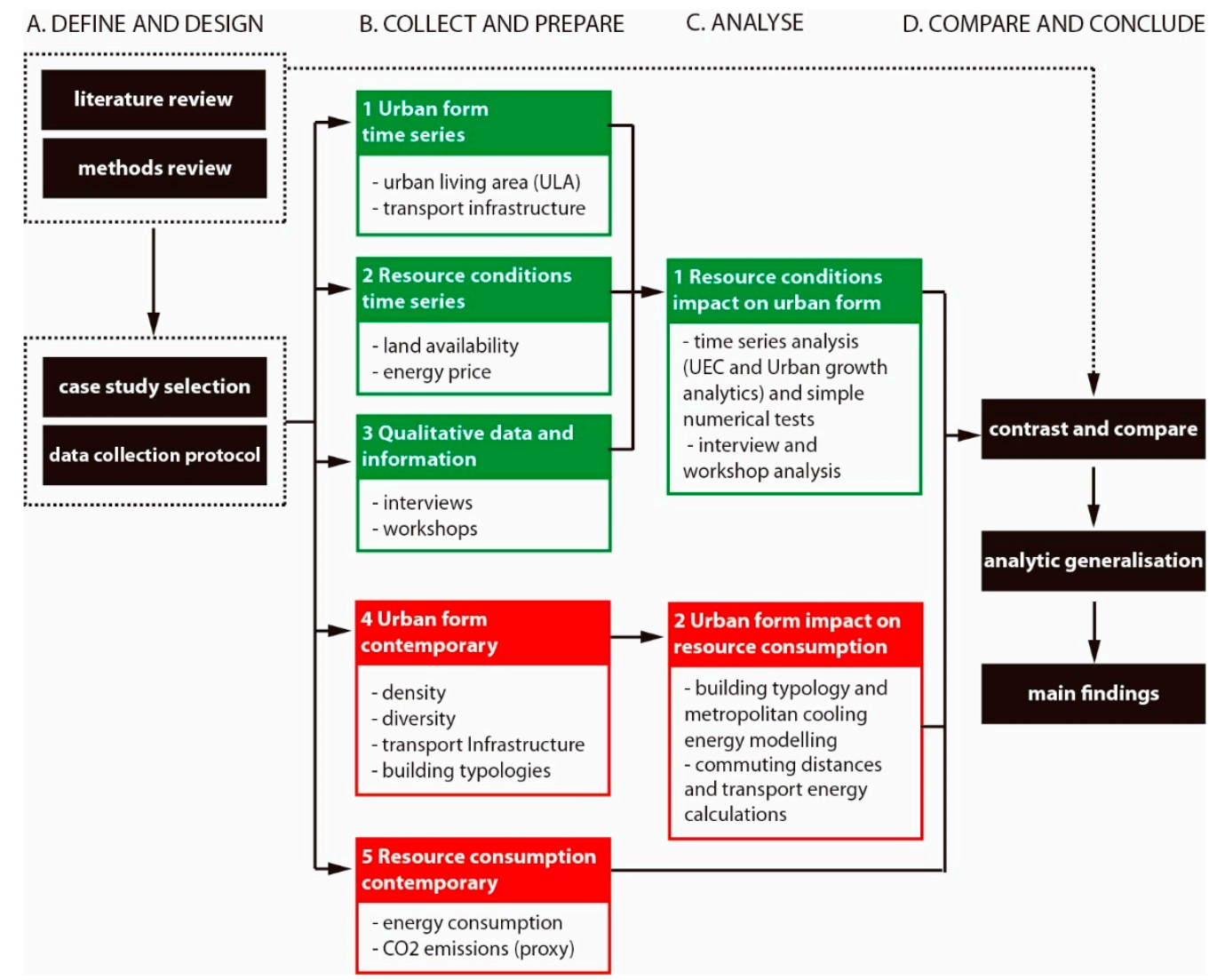

Figure 1. Research framework.

\subsection{Case Study Cities}

This research uses a comparative, multiple case study approach [96,97] to develop a deeper understanding of urban development patterns within and across Asian cities with divergent resource conditions. For this purpose, it focuses on two Gulf Cooperation Country (GCC) cities, Kuwait and Abu Dhabi, and compares them to two East Asian cities, Singapore and Hong Kong. All four case study cities are high-income Asian city states that feature divergent and, in some aspects, polar opposite natural resource conditions, urban forms and mobility patterns. The case study cities were selected as "extreme cases" (i.e., resource conditions and spatial development patterns which are extremes and opposites within an Asian context) and "critical cases" (i.e., cities that are of particular relevance for a better understanding of the implications of resource abundance and scarcity).

Both Kuwait and Abu Dhabi are useful case study cities as they have access to easily available land for new development and cheap energy, which may have created the conditions for urban sprawl and motorisation. It is also likely that low-density developments and the consequent demand for substantial investments in road infrastructure may have further reinforced the use of more individualised modes of transport and created an urban accessibility pathway characterised by sprawling and car-oriented urban development. Hong Kong and Singapore serve as useful comparative case study cities as they face severe land constraints and have high energy prices which, combined with high population pressures, may have resulted in high-density development and relatively low motorisation rates.

\subsection{Establishing the Empirical Basis}

To investigate the way in which availability and costs of natural resources (specifically land and energy) give shape to cities and, in turn, how dwelling and transport patterns impact related transport 
and building cooling energy demands, data at the macro and micro level were gathered and analysed through a mixed methods approach. This approach involves primary and secondary research including remote sensing, urban modelling, stakeholder interviews, site visits and workshops, and makes use of data visualisation and analysis at multiple spatial scales. As part of the data collection process, a number of datasets (including spatial, statistical and census data) were obtained through desktop research and local institutions. Archival research was used to locate relevant historical maps, which were subsequently geo-referenced and digitised for use in GIS (see Table A1).

As all case study areas were analysed at the macro and micro level, spatial and statistical data were collected at national, regional, metropolitan and city scales, and when possible complemented by more granular analysis at the neighbourhood, block or building level. In order to provide a historical urban overview of city growth, satellite images, aerial photography, maps and photos were collected and classified in ArcGIS 9. Detailed disaggregated population data from the most recent census were used to measure residential population distribution, residential densities and public transport accessibility levels. Public bus stop locations were identified through local published data. In addition, semi-structured interviews were carried out with key experts in each of the case study cities to triangulate data and identify key events, policies and themes related to urban development, resources (land and energy) and city growth. These were complemented with secondary research on the topic.

As there has been limited comparative work of this nature previously, the team experienced a number of challenges related to data collection, creation and reliability during the course of this research. For this reason, data for different indicators were collected through a variety of sources and cross-referenced to determine the most reliable and complete dataset for each indicator. When data were not available through formal institutional sources, spatial data were collected from open sources and big data projects such as OpenStreetMap, Google Maps and Google Earth. It is important to note that data were only collected up to the year 2015 as most of the project data collection process took place in 2016, and it was necessary to create an end date to allow for comparison.

To establish the empirical basis for the cooling energy analysis, the first step was to identify the most representative and distinctive building typologies (residential or including at least some level of housing) at the micro level in each of the four case study cities. The research then documented the urban morphologies of the most representative area for each typology at a scale of 500 by 500 metres with a focus on neighbourhood design, streets and building configurations. Through this process, five distinct building types, which include a variety of detached housing/villas, mixed use/residential apartments and iconic buildings, were identified in each city based on the most generic features of the building configurations. Most of these samples allowed for an additional "purification" of the morphological characteristics to ensure that the most prominent urban form in a given area expanded across the entire 500 by 500 metre samples. For each of the architectural types, data related to building footprint, building height and number of floors were collected, through institutional sources, expert surveys and open source websites. In addition, 3D city models of the samples were generated based on the building footprints, heights and the methods explained in Wendel et al. [98].

\subsection{Analysis}

Following the data collection stage, different forms of analysis were used to explore and compare the four case study cities at different scales. Data were analysed both quantitatively (using statistical analysis) and qualitatively (drawing on key themes, patterns from interviews, policy documents, academic literature and visualisations produced for this research) to assess whether urban development in each of the four case study cities has directly been affected by the availability and costs of land and energy, and whether different forms of urban development have led to substantial differences in resource use.

As the first step, changes in urban development were documented at the macro and micro scale, and definitions and classifications of urban form and morphologies were developed. At the macro level, 
the evolution of each city's transport infrastructure, urban footprint, work and residential densities was documented, calculated and visualised over time. Historical patterns of urban expansion in each of the cities were examined through the archived satellite images, paper maps and aerial photographs dating back to 1950. These maps were digitised, and growth in urban living areas (ULAs) ${ }^{2}$ was calculated and visualised, when possible, at 10-year intervals between 1950 and 2015.

The urban living area is the systematic spatial representation of metropolitan urban growth. It includes all the built-up areas within a metropolitan along with its open spaces that are small enough to be considered urbanised while excluding "dead" built-up spaces such as containers, oil tanks or isolated roadways. The three-step process followed for calculating built-up areas and ULAs from satellite image analysis is as follows:

- $\quad$ Step 1, satellite image processing: Landsat ETM+ images were downloaded from the NASA's Landsat database for the year 2015. A composite image was created after pan-sharpening of the downloaded image which enhanced the spatial resolution from 30 to $15 \mathrm{~m}$. The image was clipped to the study area boundary to save computation time and effort.

- Step 2, urban footprint delineation: built-up areas were identified from the imagery through the ArcGIS 9 tool "ISO cluster unsupervised classification" that uses ISO cluster and maximum likelihood classification algorithms. The identified built-up area classes were improved through visual inspection.

- $\quad$ Step 3, urban living area delineated from urban footprint: isolated roads and structures, such as containers or oil storage tanks, were erased from the identified built-up area pixels. Afterwards, all the built-up area polygons were aggregated within a distance threshold of 200 metres and enclosed open spaces which were smaller than 100,000 square metres in size were converted into urban areas through the GIS Spatial Analyst extension.

A back-casting approach was used to generate historical maps of urban living areas. The built-up polygons from the year 2015 were deleted after visual inspection if the historical image or map dataset did not show them as built-up locations.

In order to know whether the city was densifying or expanding relative to its growth, an index "urban expansion coefficient" (UEC) was computed, where:

$$
\text { Urban expansion coefficient }(\mathrm{UEC})=\frac{\% \text { change in urban living area }}{\% \text { change in population }}
$$

ArcGIS-based point buffer analysis was used to measure the share of the urban living area within various buffer distances to bus stop locations, which represented the share of the residential population within corresponding accessibility categories.

To calculate the commuting energy demand in each city (Te), firstly, the average commuting distances between all residential and workplace locations in the metropolitan (Drj) was calculated using the ArcGIS point distance tool. This distance value was subdivided by each mode according the local mode share $(\mathrm{M})$ of commuting trips obtained from the literature. The mode level commuting distance was multiplied by its standardised energy consumption values (Es) from the literature. The resulting

2 ULA is a new metric developed to represent more accurately the land where urban living takes place. It includes all built-up areas or "urban footprint", as well as small enclosed open spaces. However, it excludes large, unoccupied spaces, "dead" built-up spaces, such as isolated roadways, and areas occupied by large storage structures, such as shipping containers or oil storage tanks that are included in traditional measures of built-up areas. For discussion on urban footprints, see Angel et al. [99]. 
energy consumption per trip was multiplied by the total number of commuting trips $(J)$ which are twice the total number of metropolitan jobs, for 251 working days of the year.

$$
T e=\left\{\left(\frac{D r j}{M}\right) * E s\right\} * J * 251
$$

where $M$ and $E s$ are different for each mode used e.g., car, bus or rail, resulting in multiple individual values that are summed together to obtain combined commuting energy demand in the metropolitan.

Monthly cooling energy demand of the 500 by 500 metre urban morphology samples was calculated using a steady state energy balance model coupled to semantic 3D data models of the urban areas. The review of energy models was based on the requirement of a generic calculation with a focus on cooling energy needs as well as a method that could be connected to the semantic 3D data model, making use of automated calculation of whole districts or larger urban areas. The ISO 13790:2008 standard is a well-known and widely used calculation method to evaluate heating and cooling needs at the building scale. The standard defines steady state calculation methods at hourly, monthly and seasonal resolutions [100]. The method has been used in numerous studies and has been adopted as a national standard by many countries worldwide. The monthly ISO model also produces good results compared to other simulation software such as EnergyPlus [101]. It has also been proved that this simplified method is able to predict year-round energy needs, assuming that the dynamic parameters are correctly determined [102].

More recently, the method was used in connection to standardised semantic 3D city models in the CityGML format at different levels of detail (LOD1, LOD2, etc.). Such spatial datasets today are available for many cities worldwide [103]. Chalal et al. [104] carried out an extensive literature review on GIS-based energy calculation approaches and Koch [105] classified a number of physical as well as data-driven approaches for urban energy assessment. Eicker, et al. [106] calculated a similar steady state energy balance (DIN 18599) for calculating monthly heating energy needs for three neighbourhoods in Germany. Nouvel, et al. [107] found the results to be accurate and robust for long-term urban energy scenario development applied to an urban district.

For each representative sample, the energy needs for heating and cooling were calculated according to ISO 13790:2008 [100] based on the geometric information (surface function, area, orientation, etc.) extracted from the semantic 3D city model (Table 1 ).

Table 1. Energy needs for heating and cooling formulas.

\begin{tabular}{cc}
\hline Mode & Formula \\
\hline Cooling mode: & $Q_{C, n d}=Q_{g n}-\eta_{l s} * Q_{h t}$ \\
Heating mode: & $Q_{H, n d}=Q_{h t}-\eta_{g n} * Q_{g n}$ \\
With & $Q_{h t}=Q_{t r}+Q_{v e}=\left(H_{t r}+H_{v e} *\left(\theta_{i n t, s e t}-\theta_{e}\right) * t\right.$ \\
& $Q_{g n}=Q_{i n t}+Q_{s o l}=\left(\dot{Q}_{i n t}+\dot{Q}_{s o l}\right) * t$ \\
\hline
\end{tabular}

$H_{t r}$ and $H_{v e}$ Heat transfer coefficient by transmission and ventilation $[\mathrm{W} / \mathrm{K}]$;

$\dot{Q}_{i n t}$ and $\dot{Q}_{\text {sol }}$ Heat flows coefficient from internal sources and solar radiations [W];

$\theta_{\text {int, set }}$ Set point temperature $\left[{ }^{\circ} \mathrm{C}\right] ; \theta_{e}$ External temperature $\left[{ }^{\circ} \mathrm{C}\right]$;

$Q_{h t}$ Total heat transfer (by transmission and ventilation) [kWh];

$Q_{g n}$ Total heat gains (solar and internal gains) [kWh]; $t$ Time step [h];

$\eta_{l s}$ Utilization factor for heat losses [-];

$\eta_{g n}$ Utilization factor for heat gains [-];

$Q_{C, n d}$ Energy need for the continuous cooling mode $[\mathrm{kWh}]$

$Q_{H, n d}$ Energy need for the continuous heating mode [kWh] 
The selected ISO 13790:2008 monthly energy model was implemented using an open source-based software architecture-CityBEM-in connection with data from 3D city models in the CityGML standard (LOD2) $[108,109]$ to automate the calculation and import of GIS data. As the application to cooling energy demand has been done in few studies, a validation against TRNSYS simulation results was performed as a parallel task [108]. CityBEM is structured in four main blocks: (a) definition of building boundaries for conditioned and unconditioned spaces (b) identification of the zones (c) definition of the internal conditions for calculation of external climate and other environmental data inputs (heat transfer losses, heat gain, etc.) and (d) calculation of energy needs for cooling, for each time step and building. ${ }^{3}$

Data on building geometry were collected in the 3D CityGML format (LOD1), which allows for the identification of individual walls, roofs or floor surfaces and thus allows for the calculation of conditioned floor area and building volume. As a simplification, each building is regarded as a single zone. Data on building typology describes the building attributes, e.g., building type (single family house, apartment block, etc.) and building age, as well as building characteristics such as U-values, g-values, etc. For comparative reasons, insulation standards for all typologies were fixed to those of Kuwait. The set-point temperatures, internal gains and air change rates are averaged according to the respective conditioned used area. The values were selected based on the extensive literature review, national regulations and expert interviews. The data on weather conditions such as monthly average temperature and wind speed data were collected from Meteonorm 7.1 software as a typical meteorological year 3 (TMY3) format. The average monthly solar radiation for every building surface was calculated from a solar radiation model (PLANTING), which takes the shading of the neighbouring buildings into account [110].

Regarding the data workflow, semantic data in a CityGML format describing the building geometry and coordinates were imported into a PostgreSQL/3DCityDB database. 3DCityDB [111] is an open source package including the database schema and functions to manage, analyse and export virtual 3D city models in a CityGML standard. Based on the resulting PostgreSQL database, a Python script was used to calculate the surfaces and the volume of each building within Eclipse. The PyDev plug-in [112] was used to work with Python scripts. Building typology datasets from the expert assessment were collected in Excel or CSV format.

Climate data were based on values from Meteonorm 7.1. All information was processed using Python scripts to include the needed information in tables in the PostgreSQL database. Further software tools used for data handling and visualisation were FZKViewer [113], QGIS and FME. As a rich dataset was generated in the PostgeSQL database, the semantic spatial data at the neighbourhood scale was set to calculate macro-morphological parameters, such as building density, surface-to-volume ratio and height and surface coverage, to explore effects on cooling energy demand of different morphology types.

To summarise, the above mixed methods approach enabled our analysis across the spectrum, cutting across relationships between resource conditions and urban form, as well as urban form and resource consumption in a high-level, comprehensive way. Many studies have relied on GIS tools to assess changes in land consumption [114], analysed land cover maps to understand land cover changes in peri-urban zones [115], calculated and compared urban land cover and expansion across metropolitan cities using satellite imagery and population estimates [99] or studied changes in household energy consumption in the context of changes in land use in peri-urban areas using interviews and remote sensing [116]. This paper relied on a combination across all these methods to address our research questions across the "resource urbanisms" spectrum.

3 A detailed explanation on the implementation, equation and validation of the method is provided in [109]. The tool mainly requires four categories of input data: building geometry, building typology, outdoor temperature and solar radiation on each building surface. 


\section{Results}

\subsection{Contemporary Urban Form in the Case Study Cities}

Figure 2 illustrates the considerable difference in overall land area of Kuwait and Abu Dhabi on the one hand, and Singapore and Hong Kong on the other. While Abu Dhabi faces the lowest levels of physical constraints to development, Kuwait also has significantly more land available for development when compared with the two East Asian cities.
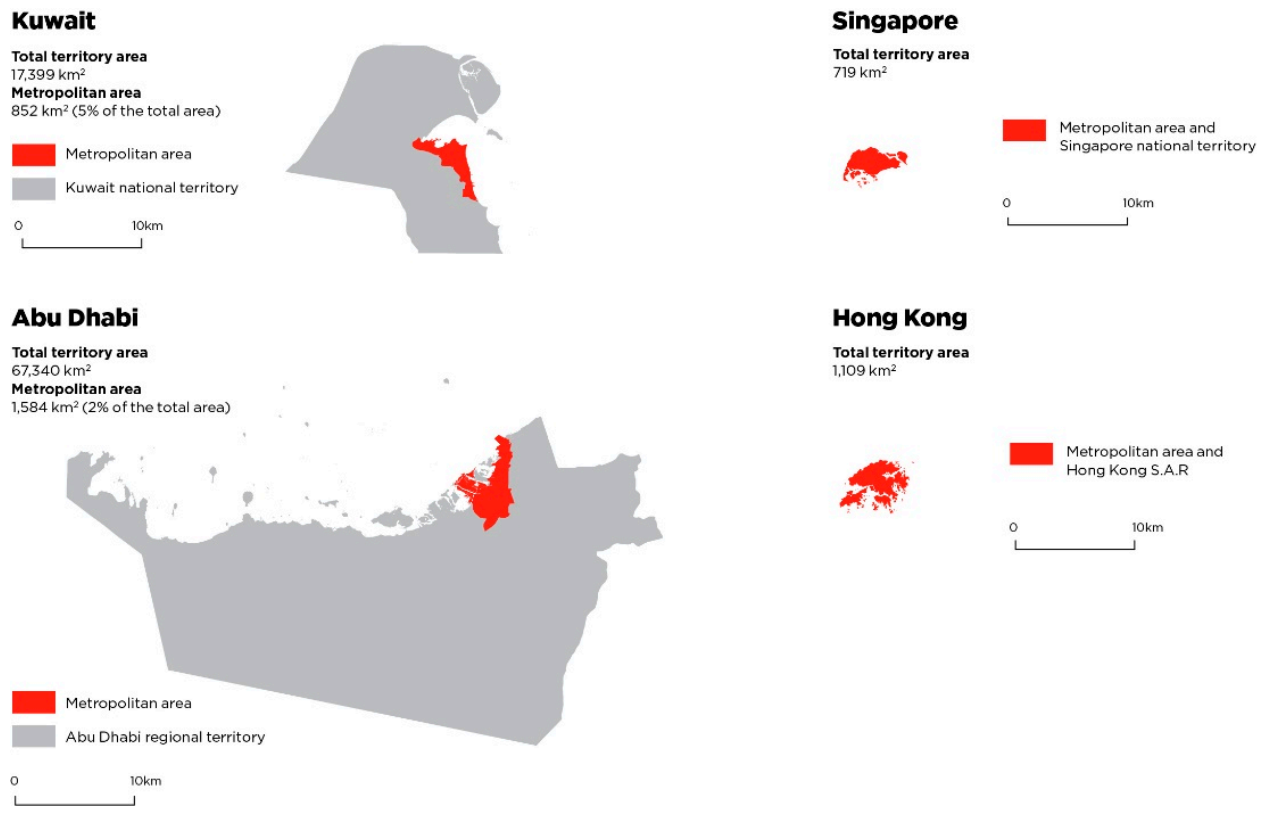

Figure 2. Case study territories/countries and metropolitan areas at the same scale.

Their diverging densities are among the most fundamental differentiators of urban form. Average densities within the urban living area range from 4428 pers $/ \mathrm{km}^{2}$ (Abu Dhabi) to 29,554 pers $/ \mathrm{km}^{2}$ (Hong Kong). A closer look at the distribution of residents by square kilometre across a 100 by 100 kilometre urban region reveals further differences. Peak densities range from 39,142 pers $/ \mathrm{km}^{2}$ in Abu Dhabi to 112,942 pers $/ \mathrm{km}^{2}$ in Hong Kong.

Furthermore, high-density neighbourhoods in Kuwait are clustered mostly in its central neighbourhoods, although the edges of the city also host a mix of high- and low-density neighbourhoods. In most cases, density peaks represent non-Kuwaiti neighbourhoods. Peaks in Abu Dhabi are unevenly distributed as they are located in the Central Business District (CBD) area and two other mainland clusters. Densities in Singapore are more homogenously distributed, while in Hong Kong they take a more polycentric shape due to natural barriers that serve as constraints to development.

When analysing the link between population densities and housing typologies, this research finds that Kuwait is the only city where the majority of the population (65 per cent) lives in low-density housing 4 . In Abu Dhabi, nearly 60 per cent of the population lives in apartments and industrial buildings, and in Singapore and Hong Kong, over three quarters of the population lives in apartment buildings. However, in Abu Dhabi, although a majority of the population lives in apartments and industrial buildings, these typologies cover only 27 per cent of the total ULA, while low-density housing consumes over 70 per cent of the total ULA. Hence, apartments and industrial areas are

4 The percentage of the population living in low-density housing also includes domestic staff. In some instances, the number of people living in low-density housing may have been overestimated as the methodology used associated each block in the metropolitan area with its dominant typology, and was limited in its ability to disaggregate further. 
characterised by substantially higher residential densities. In Hong Kong, apartments house 96 per cent of the population, and also cover 94 per cent of the total ULA, suggesting a more even distribution of the population by typology.

\subsection{From Resource Conditions to Urban Form}

This section traces changes in urban growth patterns across the four cities roughly over an 85-year period (1930-2015), explores similarities and differences in these patterns, and analyses the impact that land and energy have had on their dynamics of growth (Table 2).

In all four case study cities, increasing wealth levels and population growth are closely associated with increases in ULAs. In Kuwait, the initial increase in ULA appears to have been directly related to its first oil export shipment. Moreover, the rate of urban expansion seems to have been impacted by fluctuations in global oil prices, as well as political instability in the region, in particular with regard to its involvement in the Iraq War, which was also a period when not all data were available. As in Kuwait, the initial increase in Abu Dhabi's ULA also appears to be related to its first oil shipment. However, urban expansion in Abu Dhabi seems to be more closely tied to Sheikh Zayed's rise to power in 1966. Here, too, changes in global oil prices and GDP (in this case interconnected) seem to have affected population densities and the rate at which the city expanded. Following Sheikh Zayed's death in 2004, and the start of Sheikh Khalifa's term, a considerable increase in urban expansion can be observed for Abu Dhabi.

In Singapore, the ULA has grown consistently alongside an increase in GDP per capita. More recently, the ULA has expanded at a slower rate, leading to higher density in the city despite increased fuel affordability. In Hong Kong, the ULA increased at a faster rate than population growth until 1990, leading to a decrease in population density over time. Since 1990, the rate of urban expansion has only been slightly higher than the rate of population growth, and density levels appear to have stabilised. As can be seen, Hong Kong's ULA expanded significantly between the 1960s and 1970s due to a steady rise in wealth, and informed by the development of new towns, natural park schemes, public housing and mass transit.

Based on the urban growth analysis, we first discuss the degree to which land availability may have influenced urban form in the four cities. This is followed by presenting the same argument in relation to energy availability and costs. It includes numerical tests, using fuel price and fuel affordability as indicators of energy costs, and the urban expansion coefficient (UEC) as an indicator of urban growth. By doing so it tests whether, historically, energy costs have impacted urban growth in the four case study cities. 
Table 2. Urban growth analytics ${ }^{5}$

\begin{tabular}{|c|c|c|c|c|c|c|c|c|c|c|c|c|c|c|c|c|}
\hline \multirow[b]{2}{*}{ Decade } & \multicolumn{4}{|c|}{ Kuwait } & \multicolumn{4}{|c|}{ Abu Dhabi } & \multicolumn{4}{|c|}{ Singapore } & \multicolumn{4}{|c|}{ Hong Kong } \\
\hline & Pop & $\begin{array}{c}\text { ULA } \\
\text { [sqkm] }\end{array}$ & $\begin{array}{l}\text { GDPpc } \\
\text { [USD] }\end{array}$ & $\begin{array}{c}\text { Fuel af } \\
{[\%]}\end{array}$ & Pop & $\begin{array}{c}\text { ULA } \\
\text { [sqkm] }\end{array}$ & $\begin{array}{l}\text { GDPpc } \\
\text { [USD] }\end{array}$ & $\begin{array}{c}\text { Fuel af } \\
{[\%]}\end{array}$ & Pop & $\begin{array}{c}\text { ULA } \\
\text { [sqkm] }\end{array}$ & $\begin{array}{l}\text { GDPpc } \\
\text { [USD] }\end{array}$ & $\begin{array}{c}\text { Fuel af } \\
{[\%]}\end{array}$ & Pop & $\begin{array}{c}\text { ULA } \\
\text { [sqkm] }\end{array}$ & $\begin{array}{l}\text { GDPpc } \\
\text { [USD] }\end{array}$ & $\begin{array}{c}\text { Fuel af } \\
{[\%]}\end{array}$ \\
\hline $1930 \mathrm{~s}$ & - & $\begin{array}{c}2.5 \\
(1930)\end{array}$ & - & - & - & - & - & - & - & $\begin{array}{c}23.5 \\
(1930)\end{array}$ & - & - & - & - & - & - \\
\hline $1940 \mathrm{~s}$ & $\begin{array}{l}70,000 \\
(1947)\end{array}$ & - & - & - & - & - & - & - & - & $\begin{array}{c}50.1 \\
(1945)\end{array}$ & & & $\begin{array}{l}1,800,000 \\
(1947)\end{array}$ & $\begin{array}{c}22.0 \\
(1945)\end{array}$ & - & - \\
\hline $1950 \mathrm{~s}$ & $\begin{array}{c}206,473 \\
(1957)\end{array}$ & $\begin{array}{c}4.9 \\
(1951)\end{array}$ & - & - & - & $\begin{array}{c}7.5 \\
(1949)\end{array}$ & - & - & $\begin{array}{l}1,445,929 \\
(1957)\end{array}$ & $\begin{array}{c}75.5 \\
(1954)\end{array}$ & - & - & $\begin{array}{c}2,060,000 \\
(1950)\end{array}$ & - & - & - \\
\hline $1960 \mathrm{~s}$ & $\begin{array}{c}321,621 \\
(1961)\end{array}$ & $\begin{array}{c}45.6 \\
(1963)\end{array}$ & $\begin{array}{c}4350 \\
(1965)\end{array}$ & - & - & $\begin{array}{c}8.6 \\
(1960)\end{array}$ & - & - & $\begin{array}{l}1,646,400 \\
(1960)\end{array}$ & $\begin{array}{l}101.4 \\
(1969)\end{array}$ & $\begin{array}{c}449 \\
(1961)\end{array}$ & - & $\begin{array}{c}3,128,200 \\
(1960)\end{array}$ & - & $\begin{array}{c}437 \\
(1961)\end{array}$ & - \\
\hline $1970 \mathrm{~s}$ & $\begin{array}{c}738,662 \\
(1970)\end{array}$ & $\begin{array}{c}143.8 \\
(1977)\end{array}$ & $\begin{array}{c}3831 \\
(1970)\end{array}$ & - & - & $\begin{array}{c}27.7 \\
(1969)\end{array}$ & $\begin{array}{l}27,709 \\
(1975)\end{array}$ & - & $\begin{array}{c}2,074,507 \\
(1970)\end{array}$ & $\begin{array}{l}132.8 \\
(1983)\end{array}$ & $\begin{array}{c}925 \\
(1970)\end{array}$ & - & $\begin{array}{c}3,959,000 \\
(1970)\end{array}$ & $\begin{array}{c}67.8 \\
(1971)\end{array}$ & $\begin{array}{c}960 \\
(1970)\end{array}$ & - \\
\hline $1980 \mathrm{~s}$ & $\begin{array}{l}1,357,952 \\
(1980)\end{array}$ & $\begin{array}{c}195.2 \\
(1982)\end{array}$ & $\begin{array}{l}20,687 \\
(1980)\end{array}$ & $\begin{array}{c}0.76 \\
(1984)\end{array}$ & - & $\begin{array}{c}48.0 \\
(1978)\end{array}$ & $\begin{array}{l}42,879 \\
(1980)\end{array}$ & - & $\begin{array}{c}2,413,945 \\
(1980)\end{array}$ & $\begin{array}{l}150.4 \\
(1987)\end{array}$ & $\begin{array}{c}4927 \\
(1980)\end{array}$ & - & $\begin{array}{c}5,038,500 \\
(1980)\end{array}$ & $\begin{array}{c}114.0 \\
(1981)\end{array}$ & $\begin{array}{c}5700 \\
(1980)\end{array}$ & - \\
\hline $1990 \mathrm{~s}$ & $\begin{array}{l}1,936,656 \\
(1990)\end{array}$ & $\begin{array}{c}281.7 \\
(1990)\end{array}$ & $\begin{array}{c}8951 \\
(1990)\end{array}$ & $\begin{array}{c}1.12 \\
(1990)\end{array}$ & - & $\begin{array}{c}93.7 \\
(1990)\end{array}$ & $\begin{array}{l}27,989 \\
(1990)\end{array}$ & $\begin{array}{c}0.72 \\
(1998)\end{array}$ & $\begin{array}{c}3,047,132 \\
(1990)\end{array}$ & $\begin{array}{l}184.5 \\
(1991)\end{array}$ & $\begin{array}{l}11,864 \\
(1990)\end{array}$ & $\begin{array}{c}4.1 \\
(1991)\end{array}$ & $\begin{array}{c}5,704,500 \\
(1990)\end{array}$ & $\begin{array}{c}192.2 \\
(1992)\end{array}$ & $\begin{array}{l}13,486 \\
(1990)\end{array}$ & $\begin{array}{c}3.9 \\
(1991)\end{array}$ \\
\hline $2000 s$ & $\begin{array}{l}2,088,745 \\
(2000)\end{array}$ & $\begin{array}{l}330.0 \\
(2000)\end{array}$ & $\begin{array}{l}19,545 \\
(2000)\end{array}$ & $\begin{array}{c}1.02 \\
(2000)\end{array}$ & $\begin{array}{c}809,000 \\
(2005)\end{array}$ & $\begin{array}{l}154.4 \\
(2000)\end{array}$ & $\begin{array}{l}34,208 \\
(2000)\end{array}$ & $\begin{array}{c}0.88 \\
(2000)\end{array}$ & $\begin{array}{l}4,027,887 \\
(2000)\end{array}$ & $\begin{array}{l}218.0 \\
(2000)\end{array}$ & $\begin{array}{l}23,793 \\
(2000)\end{array}$ & $\begin{array}{c}3.4 \\
(2000)\end{array}$ & $\begin{array}{c}6,665,000 \\
(2000)\end{array}$ & $\begin{array}{r}223.9 \\
(2000)\end{array}$ & $\begin{array}{l}25,757 \\
(2000)\end{array}$ & $\begin{array}{c}3.1 \\
(2000)\end{array}$ \\
\hline $2010 s$ & $\begin{array}{c}3,576,674 \\
(2010)\end{array}$ & $\begin{array}{l}380.9 \\
(2006)\end{array}$ & $\begin{array}{l}37,725 \\
(2010)\end{array}$ & $\begin{array}{c}0.53 \\
(2010)\end{array}$ & $\begin{array}{l}1,266,125 \\
(2010)\end{array}$ & $\begin{array}{l}317.0 \\
(2006)\end{array}$ & $\begin{array}{l}34,342 \\
(2010)\end{array}$ & $\begin{array}{c}1.46 \\
(2010)\end{array}$ & $\begin{array}{l}5,076,732 \\
(2010)\end{array}$ & $\begin{array}{l}224.6 \\
(2007)\end{array}$ & $\begin{array}{l}46,570 \\
(2010)\end{array}$ & $\begin{array}{c}3.0 \\
(2010)\end{array}$ & $\begin{array}{c}7,024,200 \\
(2010)\end{array}$ & & $\begin{array}{l}32,550 \\
(2010)\end{array}$ & $\begin{array}{c}4.0 \\
(2010)\end{array}$ \\
\hline 2015 & $\begin{array}{c}4,178,572 \\
(2015)\end{array}$ & $\begin{array}{l}424.3 \\
(2015)\end{array}$ & $\begin{array}{l}29,301 \\
(2015)\end{array}$ & $\begin{array}{c}0.68 \\
(2015)\end{array}$ & $\begin{array}{l}1,720,211 \\
(2010)\end{array}$ & $\begin{array}{l}388.5 \\
(2015)\end{array}$ & $\begin{array}{l}40,439 \\
(2015)\end{array}$ & $\begin{array}{c}1.24 \\
(2015)\end{array}$ & $\begin{array}{c}5,535,002 \\
(2015)\end{array}$ & $\begin{array}{l}232.4 \\
(2015)\end{array}$ & $\begin{array}{l}52,889 \\
(2015)\end{array}$ & $\begin{array}{c}3.0 \\
(2015)\end{array}$ & $\begin{array}{l}7,305,700 \\
(2015)\end{array}$ & $\begin{array}{c}247.2 \\
(2015)\end{array}$ & $\begin{array}{l}42,328 \\
(2015)\end{array}$ & $\begin{array}{c}3.8 \\
(2015)\end{array}$ \\
\hline
\end{tabular}

Value (source year) $\mid$ Pop = population; ULA = urban living area; GDPpc = GDP per capita; Fuel af = Fuel affordability.

5 Sources: Pop [117-121], ULA (authors based on GIS remote sensing) and GDP pc and Fuel af (from World Bank [122]). 


\subsubsection{Land Availability and Urban Growth}

In Kuwait, Abu Dhabi, Singapore and Hong Kong, land availability appears to be one of the most important variables shaping the nature of urban growth which was also confirmed in our research interviews and workshops. As referenced above, simply in terms of total land area, Singapore's total territory $\left(719 \mathrm{~km}^{2}\right)$ makes up four per cent of Kuwait's total territory $\left(17,399 \mathrm{~km}^{2}\right)$, and a mere one per cent of Abu Dhabi's total territory $\left(67,340 \mathrm{~km}^{2}\right)$. Similarly, Hong Kong's total territory $\left(1109 \mathrm{~km}^{2}\right)$ makes up six per cent of Kuwait and only two per cent of Abu Dhabi's total territories, limiting the space for urban growth and the type of development that can take place (Figure 2). It is important to note that while land constraints in each of the cities seemingly serve as disadvantages in terms of urban growth, they also serve as natural barriers to unfettered urban development, and to some degree help improve resource efficiency and the environment.

Land availability, however, is not simply a function of a territory's total land area, but also of physical constraints to development and population pressures. In Hong Kong and Singapore, urban development cannot take place on $52 \%$ and $41 \%$ of the total territory respectively primarily due to natural and other land-use constraints (Figure 3).
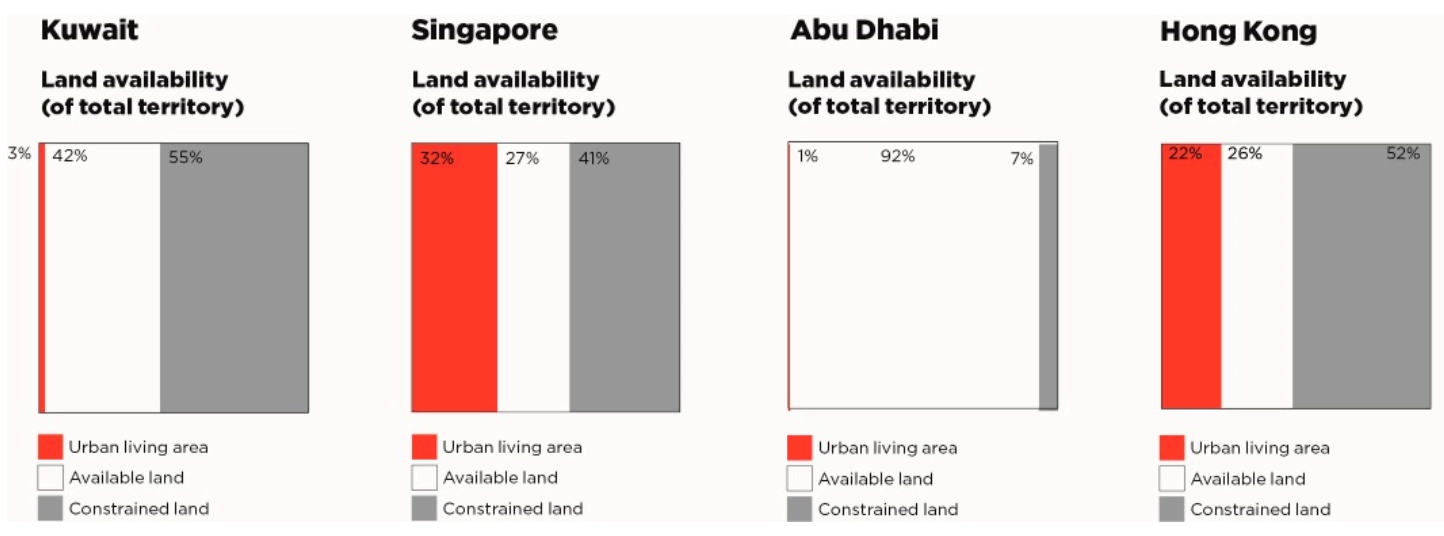

Figure 3. Land availability analysis.

Adding to these differences in territory and land constraints, population levels in Hong Kong are nearly three times higher than Abu Dhabi's and twice as high as Kuwait's, while population levels in Singapore are 1.3 times higher than in Kuwait and nearly three times higher than in Abu Dhabi. As a result, Singapore and Hong Kong face both greater population pressures than Kuwait and Abu Dhabi and have less land available for growth. Therefore, land availability on its own has necessitated the adoption of compact development policies including the development of high-rise apartments for public housing, controls on private vehicle ownership and the prioritisation of an extensive and well-functioning public transport network ${ }^{6}$. In addition, to support high population numbers, both Singapore and Hong Kong have also reclaimed land from the sea, primarily for industrial, housing and infrastructure purposes. Since 1960, Singapore has reclaimed 19 per cent of its total land area [123], and Hong Kong has reclaimed six per cent of its total land area since 1887 [124]. To meet future needs, Singapore also aims to reclaim more land, develop some reserved land, recycle land with low-intensity use and intensify new developments [125].

In contrast, land availability in Kuwait and Abu Dhabi has enabled their governments to distribute land and provide nationals with housing welfare in the form of large villas that are connected to the

6 Singapore's 2013 Land Use Plan states: “In Singapore, travel needs must be met largely by public transport as it is the most space-efficient way of transporting large numbers of people. Our limited land supply also does not allow us to build ever more roads and other facilities for private transport in an unrestrained way. We aim to achieve a public transport mode share of $70 \%$ of journeys during the morning peak hours by 2020 , and $75 \%$ by $2030 "$, (p. 41 ). 
rest of the city through extensive road networks. Low-density housing, together with a single zoning system that segregates land use (a dominant mode of planning in the 1950s-1970s), has led to even higher car dependency and urban sprawl over time. Overall, the availability of vast stretches of land has allowed both Kuwait and Abu Dhabi to meet their modernist aspirations and simultaneously improve living conditions for the national population.

Although Singapore and Hong Kong face more land pressures than Kuwait and Abu Dhabi, the cost of land is high in all four cities. The key reason being that the welfare state in Kuwait and Abu Dhabi owns the majority of the land and, apart from providing citizens with land for free, or at minimum cost, for housing (and some non-residential use in Abu Dhabi), supply of land into the private market is limited, increasing the cost of the available, non-state-owned land in the process. As a result, land availability and government policies and visions, as well as wealth from oil, rather than land costs on their own, have been influential in shaping Kuwait and Abu Dhabi's urban form.

In Singapore and Hong Kong, land scarcity has directly resulted in high land costs, which has incentivised developers to construct high-density buildings that provide more housing in less space, and allowed them to maximise profits and returns on investment. ${ }^{7}$ In Hong Kong, the high costs of land have also forced lower-income residents to live in extremely small spaces in poor conditions. Here, land scarcity, government policies and high land costs together appear to have a more direct influence on urban form.

\subsubsection{Energy Affordability and Urban Growth}

The availability of oil in Kuwait and Abu Dhabi is important insofar as it is the source of wealth through which large-scale urban development has taken place in the two cities. The discovery of oil in both cities created the perception that an "endless" source of wealth could finance city growth, and allowed them to modernise and improve living conditions in a short period of time. With increasing oil revenues, both Kuwait and Abu Dhabi chose to subsidise energy for residential, commercial and transport purposes, making it more affordable for citizens to own a car, live in air-conditioned houses and adopt modern lifestyles, slowly changing the lived experiences and geographies of both cities. Energy availability, use and costs enabled, incentivised and supported the development of consumption cities in Kuwait and Abu Dhabi (Table 3). Yet, it is difficult to determine whether it is their natural resource endowment or their general economic wealth levels that has directly impacted on urban form in both cities.

Table 3. UEC plus key price indicators ${ }^{8}$.

\begin{tabular}{lccccccccccc}
\hline & \multicolumn{3}{c}{ Kuwait } & \multicolumn{4}{c}{ Abu Dhabi } & \multicolumn{3}{c}{ Singapore } & \multicolumn{3}{c}{ Hong Kong } \\
\hline Decade UEC & FPSD & GDPpc & UEC & FPSD & GDPpc & UEC & FPSD & GDPpc & UEC & FPSD & GDPpc \\
\hline $1930-19393.8$ & - & - & - & - & - & 2.7 & - & - & - & - & - \\
$1940-19490.7$ & - & - & - & - & - & 1.9 & - & - & - & - & - \\
$1950-19592.6$ & - & - & 0.2 & - & - & 0.5 & - & - & 1.1 & - & - \\
$1960-19691.4$ & - & - & 1.2 & - & - & 0.8 & - & - & 1.8 & - & - \\
$1970-19791.3$ & - & 3831 & 0.2 & - & - & 1.3 & - & 925 & 2.6 & - & 960 \\
$1980-19891.7$ & 0.1 & 20,687 & 1.4 & - & 42,879 & 1.6 & - & 4927 & 3.9 & - & 5700 \\
$1990-19992.9$ & 0.1 & 8951 & 1.4 & 0.2 & 27,989 & 0.7 & 0.6 & 11,864 & 1.6 & 0.6 & 13,486 \\
$2000-20090.3$ & 0.2 & 19,545 & 1.5 & 0.3 & 34,208 & 0.2 & 0.8 & 23,793 & 1.4 & 0.8 & 25,757 \\
$2010-20150.4$ & 0.2 & 37,725 & 0.4 & 0.5 & 34,342 & 0.3 & 1.4 & 46,570 & 0.8 & 1.3 & 32,550 \\
\hline
\end{tabular}

UEC = urban expansion coefficient at end of decade; FPSD = fuel price at start of decade; GDPpc-GDP per capita at start of decade.

\footnotetext{
7 According to Rowe [126], developers compete with each other to construct taller buildings, particularly when rents are high and property values are rising.

8 Sources: UEC [117-121] and GIS remote sensing, Fuel and GDP (from World Bank [122]).
} 
The lack of sufficient indigenous energy sources in Singapore and Hong Kong makes it critical for both city states to secure a "reliable and diversified supply of competitively priced energy" while devising ways to become more self-sufficient and efficient in this realm [127]. As a result, when compared to Kuwait and Abu Dhabi, both Singapore and Hong Kong have focused more closely on improving energy efficiency, designing various sustainability initiatives, particularly related to building design, improving international cooperation and simultaneously exploring alternative energy options that are suitable for the geography and climate. Singapore has set up its own oil refineries as a means to generate wealth and reduce dependency on imports. In terms of energy costs, the dependence on energy imports translates into high fuel and electricity prices, which, along with a range of other transport and land-use policies, have allowed both governments to maintain low motorisation levels, and focus on improving pedestrian and public transport infrastructure.

To assess the impact of fuel prices on densification patterns in each of the cities, Figure 4 explores the relationship between fuel price and urban expansion coefficient (UEC) over time. In line with recent research that suggests that fuel prices are linked to urban densities, the results show some correlation between fuel prices and densification patterns in the four case study cities. Higher fuel prices at the beginning of each decade tend to be associated with a lower UEC for the following ten-year period.

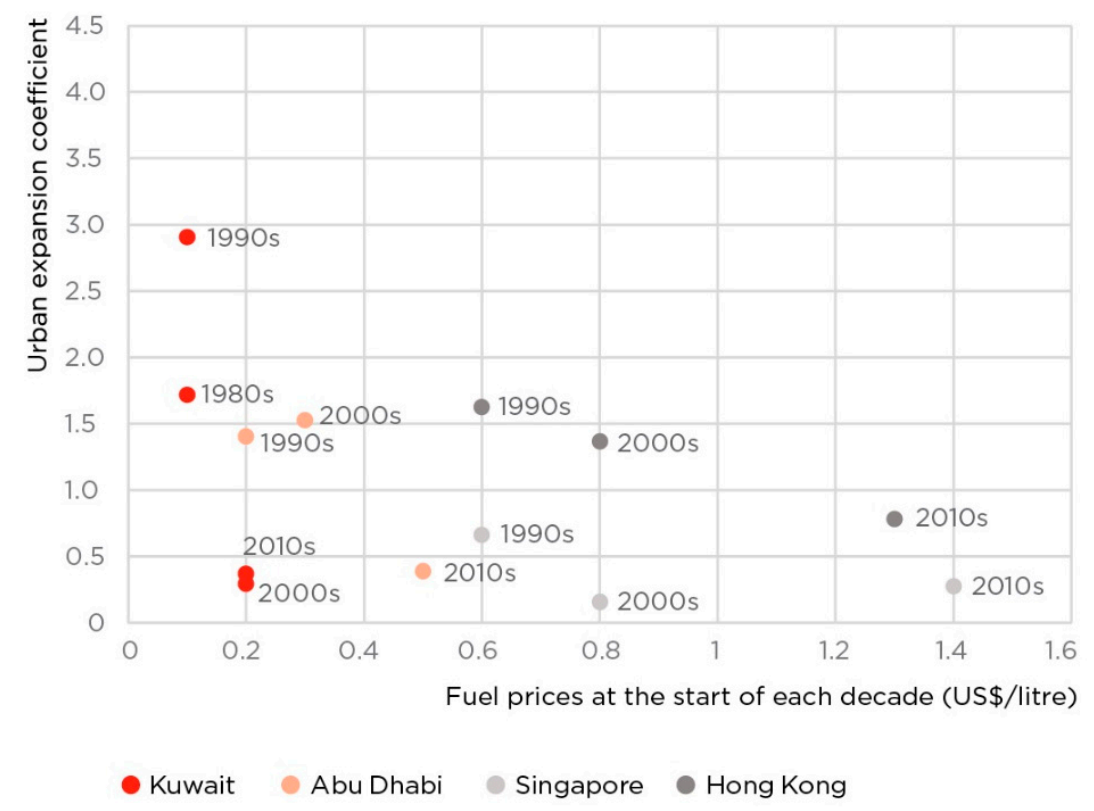

Figure 4. Fuel prices and urban expansion by decade.

Of further interest is not only the absolute level of fuel prices but how fuel affordability impacts urban expansion. Figure 5 illustrates this relationship and suggests in this case a certain positive correlation between fuel affordability and the UEC. In both Abu Dhabi and Hong Kong, lower fuel affordability levels appear to be related to greater densification in the city. In Singapore, that relationship is not so evident but suggests that greater fuel affordability levels appear to be related to the city's de-densification. In Kuwait, however, it appears that fuel affordability has had no impact on changes in densification levels in the city. This may be due to the very low price of fuel relative to income. 


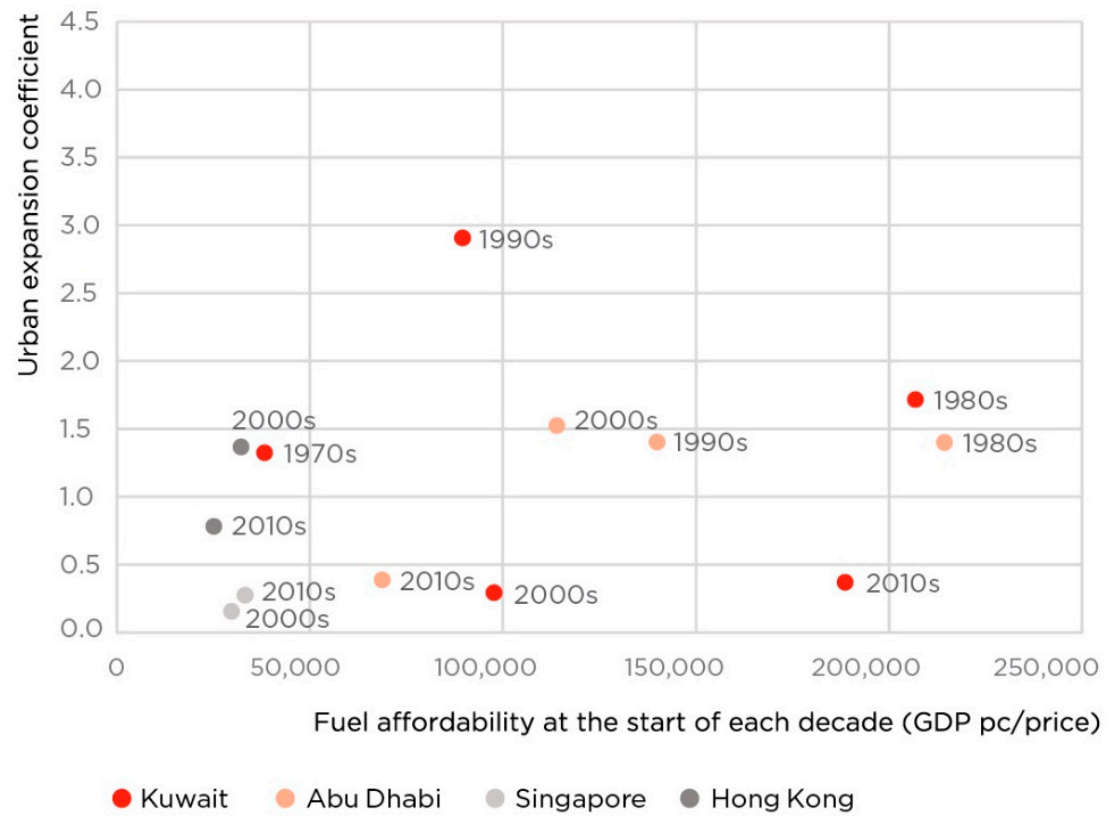

Figure 5. Fuel affordability and urban expansion by decade.

To summarise, energy availability and costs have played a more integral role in shaping urban growth in Kuwait and Abu Dhabi, as compared to Singapore and Hong Kong where land constraints, government policies and other factors have influenced the way that the cities have grown in a more direct way. In general, natural resource availability and costs have played a significant role in shaping urban built environments in the four case study cities, yet this research confirms that a country's economic base and the way in which natural resources are used and extracted are also of key importance. Moreover, land as essentially a "non-tradable" natural resource appears to hold greater significance than the availability of other natural resources in influencing urban form.

\subsection{From Urban Form to Resource Consumption}

As introductory backdrop for presenting our detailed results, Figure 6 illustrates our calculations for global patterns of urban form and resource use and positions the case studies based on empirical data. More specifically, the figure presents the relationship between metropolitan densities ${ }^{9}$ and energy use per capita for different countries. It shows that a strong negative correlation exists between urban density and energy use, with lower urban density linked to higher energy use. As seen in the graph, Kuwait and Abu Dhabi fall on one end of the spectrum with low urban densities and high energy use. Interestingly, Kuwait and Abu Dhabi's energy use is even higher than the already relatively low metropolitan density levels would suggest. This may be due to a range of factors including climate, wealth levels and housing policies providing nationals with low-density housing. In addition, it is important to note that in both Kuwait and Abu Dhabi, aside from low urban density, high energy use is also likely to be driven by large air-conditioned homes and low energy prices.

At unusually high density levels, Singapore and Hong Kong have average levels of energy consumption, but higher than the global relationships seem to suggest. In other words, they consume more energy than other countries with similar urban density levels. This is mostly a result of Singapore's

9 The metropolitan density value was determined by identifying the 2010 metropolitan-wide population density of one city per country (selecting the metropolitan region with the highest average density). This data was derived from the built-up area density of the Atlas of Urban Expansion [128]. For the four case study cities, the metropolitan density was calculated based on by the Urban Living Area 2015 (ULA) measure developed by LSE Cities. 
and Hong Kong's significantly higher wealth levels compared to countries at similar urban densities. The industrial composition in Singapore may also play a role.

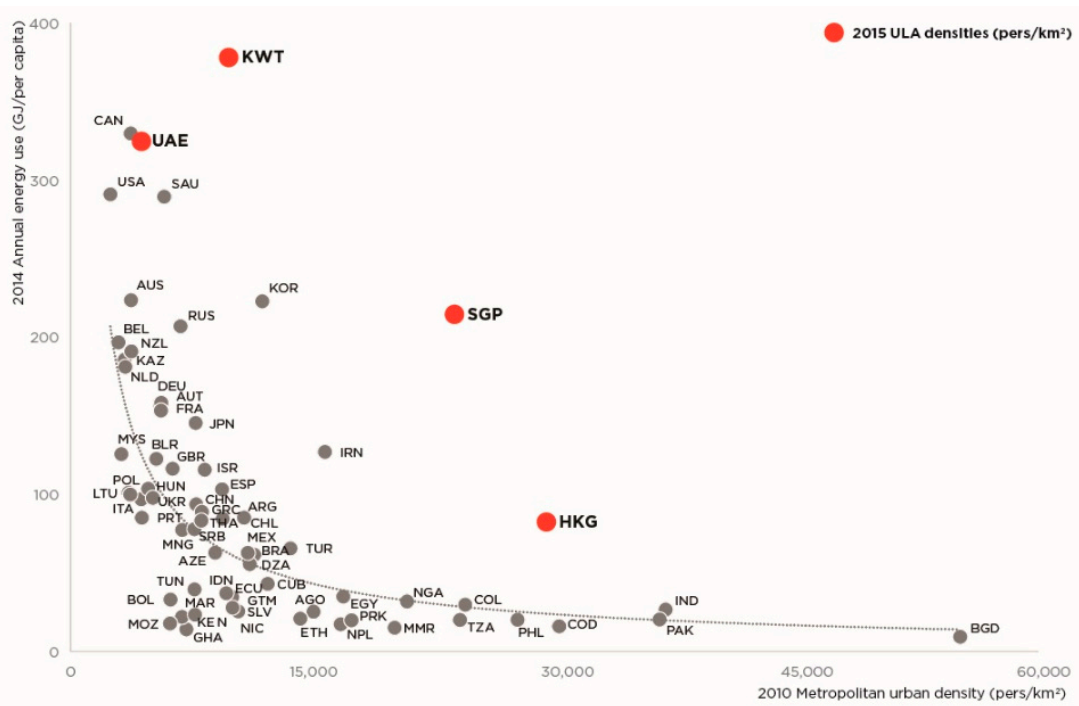

Figure 6. Energy use per capita and metropolitan density $(2014)^{10}$.

In 2014, Kuwait's and the UAE's annual energy consumption per capita was 375 GJ and 325 GJ, respectively, compared to 214 GJ in Singapore and 82 GJ in Hong Kong [129]. To a considerable degree, this difference may indeed be related to their respective urban forms, as a large proportion of their energy demand stems from buildings and transport systems. In particular, the size and arrangement of buildings and the degree of dependence on private motorised modes directly impact a city's energy requirements and resource consumption patterns. This section explores the extent to which the above differences in energy consumption between the four cities can be theoretically calculated based on their differences in urban form, in turn affecting the residential and transport energy demands.

In Singapore and Hong Kong, the residential sector contributed 27 per cent and 15 per cent, respectively, to their total electricity consumption. In Kuwait, however, it contributed to 65 per cent of total electricity consumption, particularly due to air-conditioning use in the summer months. ${ }^{11}$ In the $\mathrm{UAE}$, it contributed to 34 per cent of total electricity consumption. ${ }^{12}$ Yet its share is likely to rise in the coming years; a recent study found that cooling energy use in contemporary buildings in Abu Dhabi is significantly higher than in traditional buildings, and limited actions have been taken to reduce their energy use [133]. The share of transport energy demand of the total energy demand ranges from 23 per cent to 29 per cent [134].

\subsubsection{Cooling Energy Demand Induced by Urban Morphologies}

Three key aspects are commonly identified as explanatory factors for the energy demand required for adjusting ambient air temperature inside buildings: human behaviour alongside temperature expectations, technology and building design [67,79]. Put together, these factors explain an up to twenty-fold difference that can be observed for energy demand in buildings [80]. Based on a study of heat energy demand in four European cities, [67] have shown that urban morphology-induced heat energy efficiency is significant and can lead to a difference in heat energy demand of up to a factor of six.

10 Source: authors' illustration based on data from World Bank [129] and Lincoln Institute et al. [130].

11 According to Al-Mutairi et al. [131], "residential air conditioners consume $58.4 \%$ of the total electricity delivered by power plants at peak usage time on a hot summer day in Kuwait".

12 Residential contribution to total electricity consumption from IEA 2015 Stats [132]. 
The results from the energy demand modelling exercise established the basis for analysing the effects of different urban morphologies through their morphological parameters (building density; surface-to-volume ratio; building height and surface coverage) on cooling energy demand. Results should be interpreted as being indicative of the relative differences between cooling energy demands of the different morphology types, and not as absolute values to be compared to real building cooling energy consumption. The data presented in Figure 7 analyses each city morphology within their respective local climates, also limiting the direct comparison across cities.

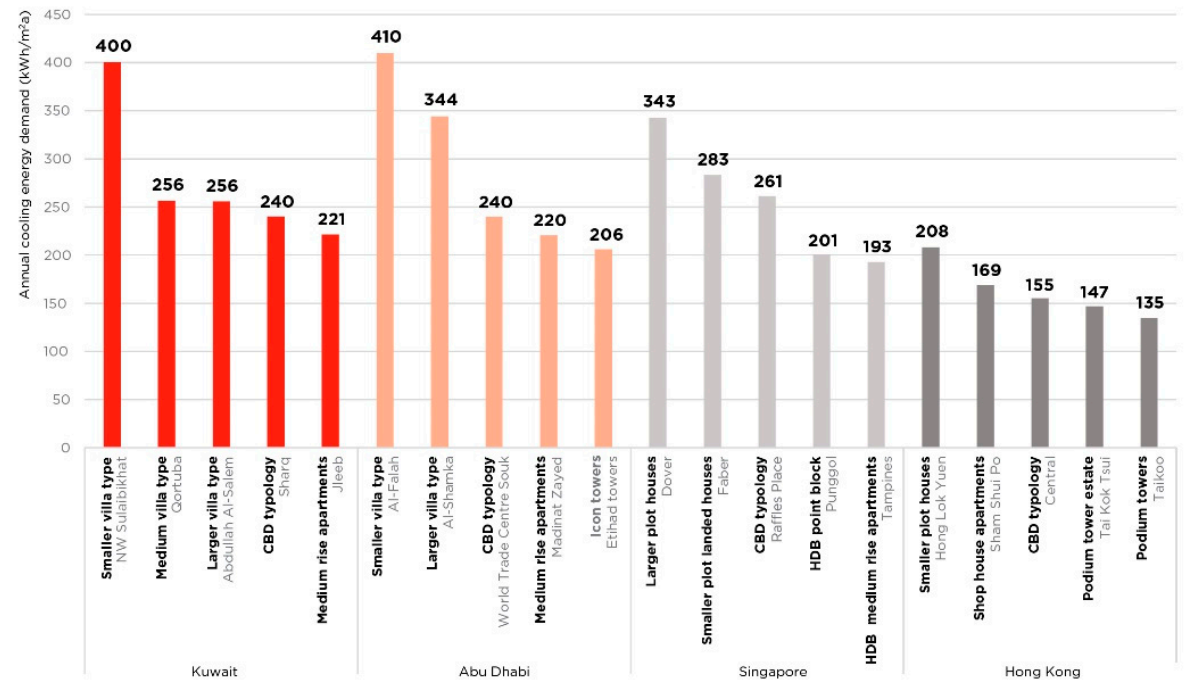

Figure 7. Annual cooling energy need in the 20 typologies.

Turning to the results of the cooling energy simulation, the modelling exercise identified considerable differences in the cooling energy demands across the urban morphology samples. A factor of three difference exists between the most energy-efficient typology, Hong Kong's Taikoo (podium towers) with $135 \mathrm{kWh} / \mathrm{m}^{2}$ and Abu Dhabi's Al-Falah (smaller villa type) with $410 \mathrm{kWh} / \mathrm{m}^{2}$. Overall, the Hong Kong samples feature significantly lower levels of cooling energy demands compared to the other three cities. With the exception of CBD samples and the icon towers (Etihad Towers) in Abu Dhabi (all cases where the window to wall ratio is higher and contributes to higher energy consumption), mid- and high-rise apartment typologies generally have lower cooling energy needs than low-density villas, which relatively consume the highest amount of cooling energy.

A closer examination of the relationship between cooling energy demand and urban morphology characteristics such as building density, building height and surface coverage confirms the initial observations (Figure 8). As shown in the same figure, there is a negative correlation between cooling energy demand and building density (FAR), with lower densities associated with higher cooling energy demand. Particularly at density levels of below and around FAR 1, cooling energy demands are considerable higher, often twice the value compared to typologies with FAR 3 or more. Similarly, there is a negative correlation between average built height and cooling energy demand, with low-rise buildings requiring higher cooling energy than mid- and high-rise buildings. Above a height of five floors, however, the variation in heat energy demand becomes considerably smaller, suggesting diminishing energy-efficiency returns with increased building height beyond this point. By contrast, the surface coverage of buildings reveals a less striking relationship with cooling energy demand. 


\section{Density and cooling energy demand}

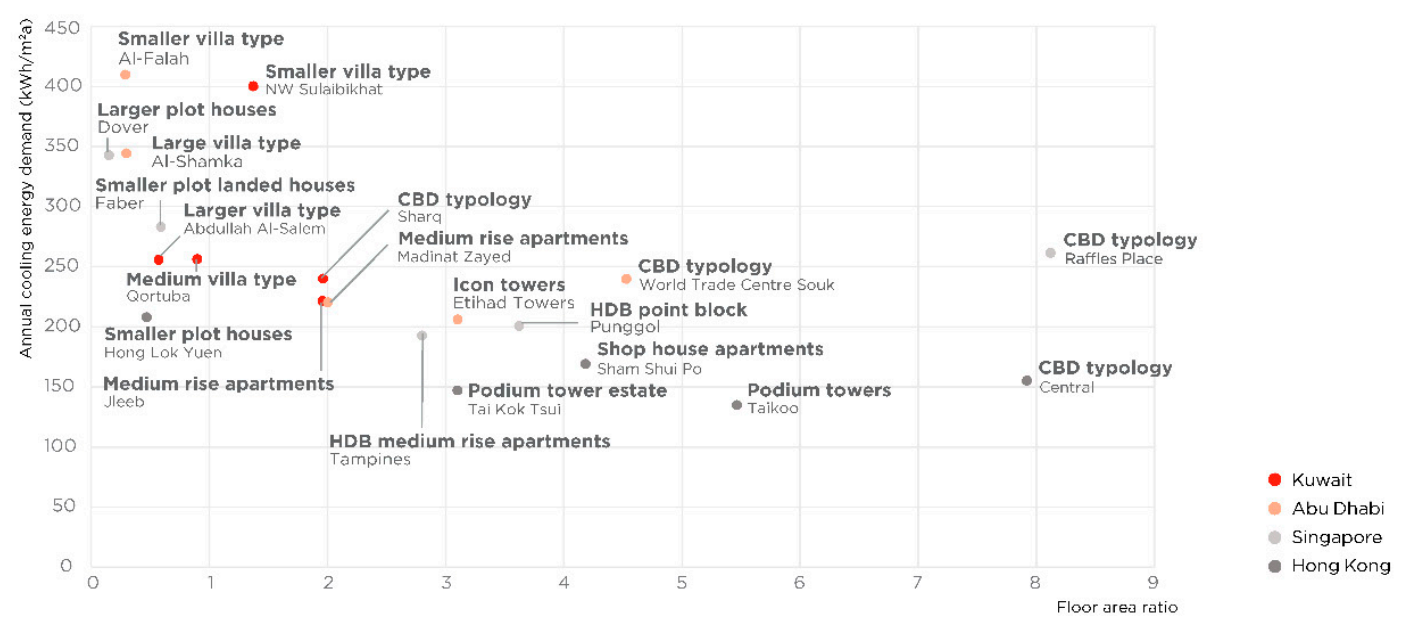

\section{Building height and cooling energy demand}

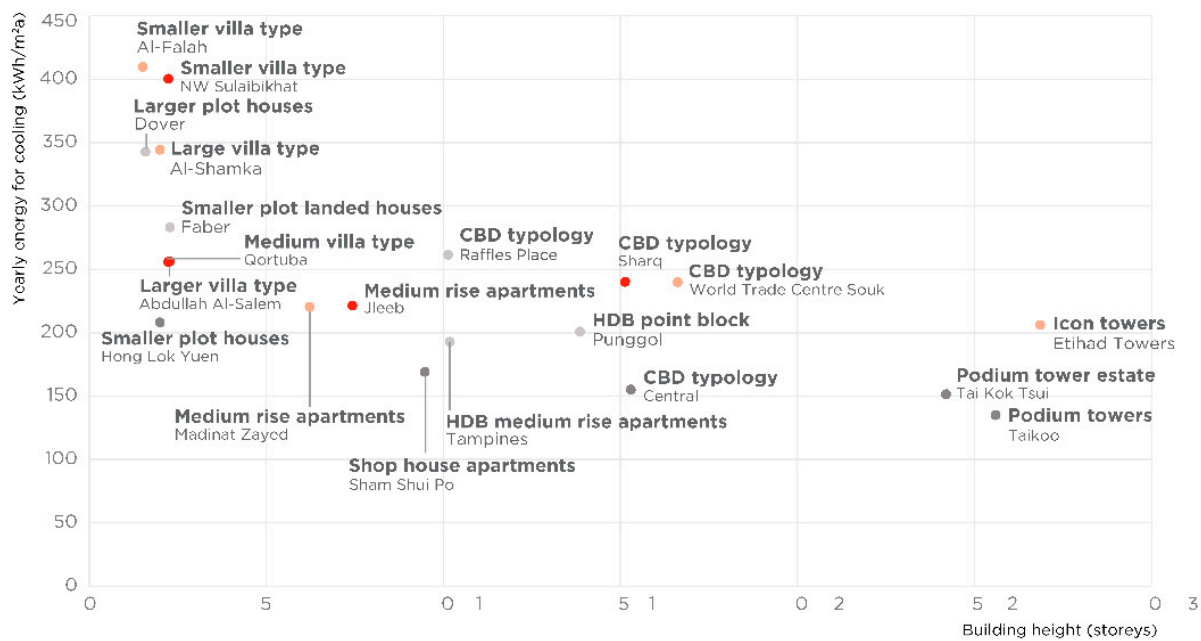

Surface coverage and cooling energy demand

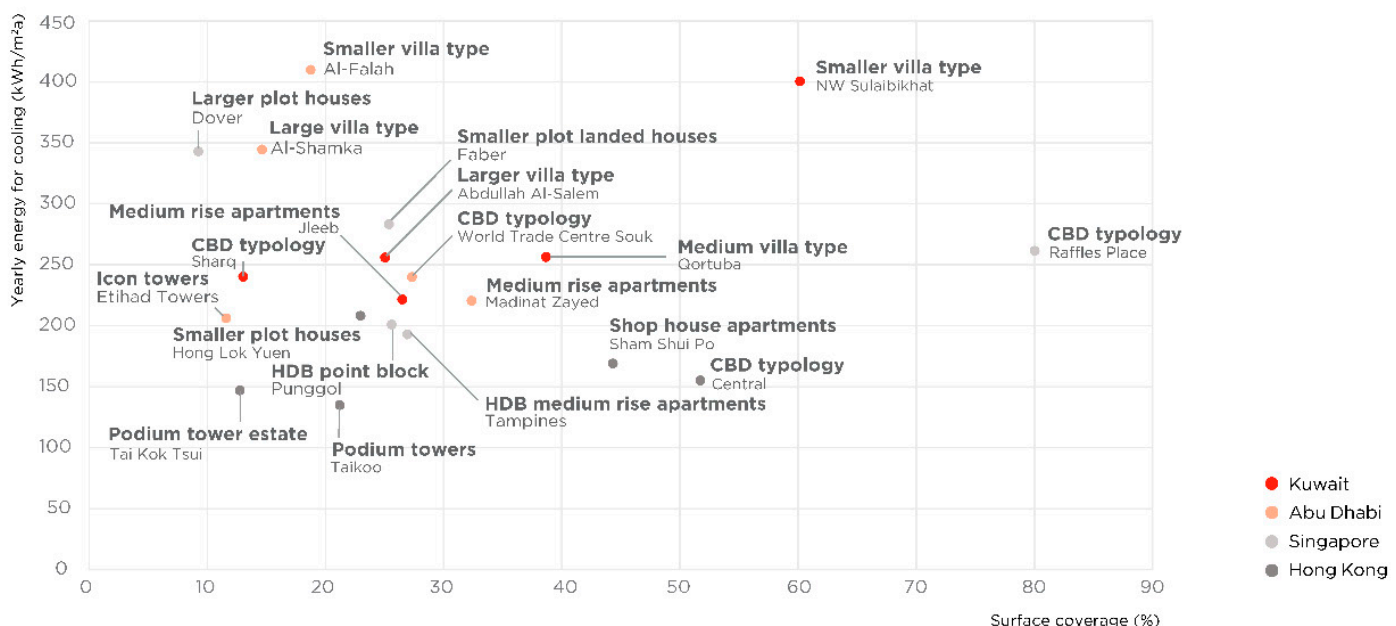

Figure 8. Urban morphology and cooling energy demand. 
For calculating the theoretical, metropolitan-wide cooling energy demand, the results from the cooling energy demand modelling above for the five most representative urban typologies (Figure 7) were combined with the classification and disaggregation of the ULA into dominant typologies of urban form. Through an analysis of densities and morphological similarities, all dominant residential typologies were assigned to one of the five urban morphology samples used in the micro-level cooling energy simulations. This made it possible to calculate the aggregate values of energy consumption for each of the five typologies based on their local prevalence. As most areas will have some level of mixed use (population and jobs), an average mixed-use value per typology was calculated for Kuwait and Hong Kong and added to all four cities (Kuwait values to Abu Dhabi and Hong Kong values to Singapore typologies) ${ }^{13}$.

When compared with international IEA values for residential energy consumption per capita, these results present consistently higher values of energy consumption (mostly due to their mix use nature, assumption of comparability between all the typologies in each cluster and the nature of urban living area definition which includes small open spaces and spaces of mobility), but seem to be keeping the same hierarchy between the four cities' levels of consumption (Table 4). A factor of three is the difference between Singapore, the city most energy-efficient per capita $(9714 \mathrm{kWh} / \mathrm{pc}$ ) and Abu Dhabi with $27,787 \mathrm{kWh} / \mathrm{pc}$ (when considering a $100 \%$ occupation of the dominantly residential areas with one of the five urban typologies and respective levels of consumption). Due to limitations of the approach, and methodological differences between the project and IEA values, these results should be interpreted as being indicative of the relative differences between residential cooling energy demands of the different cities, and not as absolute values to be compared to real cooling energy consumption.

Table 4. Metropolitan energy consumption levels per city ${ }^{14}$.

\begin{tabular}{|c|c|c|c|c|c|c|}
\hline & $\begin{array}{c}\text { Total } \\
\text { Population } \\
\text { Included } \\
\text { (pop + jobs) }\end{array}$ & $\begin{array}{c}\text { Total Area } \\
\text { Included } \\
\left(\mathbf{k m}^{2}\right)\end{array}$ & $\begin{array}{c}\text { Total Floor } \\
\text { Space } \\
\left(\mathbf{k m}^{2}\right)\end{array}$ & $\begin{array}{c}\text { Total } \\
\text { Residential } \\
\text { Energy } \\
(\mathbf{k W h} / \mathbf{a})\end{array}$ & $\begin{array}{c}\text { Total Residential } \\
\text { Energy per } \\
\text { Capita } \\
(\mathbf{k W h} / \mathrm{a} / \mathrm{pc})\end{array}$ & $\begin{array}{c}\text { IEA Total } \\
\text { Residential } \\
\text { Energy per } \\
\text { Capita } \\
(\mathbf{k W h} / \mathrm{a} / \mathrm{pc})\end{array}$ \\
\hline Kuwait & $4,434,990$ & 297 & 367 & $116,386,228,075$ & 26,243 & 7490 \\
\hline Abu Dhabi & $1,586,812$ & 254 & 156 & $44,093,145,882$ & 27,787 & 24,576 \\
\hline Singapore & $6,485,792$ & 145 & 300 & $63,002,229,372$ & 9714 & 1477 \\
\hline Hong Kong & $8,792,955$ & 205 & 711 & $101,986,297,713$ & 11,599 & 2218 \\
\hline
\end{tabular}

Note: (pop + jobs) Total population that include resident population and an added value of population corresponding to the proportion of jobs per typology category.

To conclude, this section has shown that there is a negative correlation between building density and cooling energy demand. Low-rise, low-density buildings are likely to have higher cooling energy demand. Moreover, an increase in density at lower density levels is likely to create the greatest impact in terms of a reduction in cooling energy.

\subsubsection{Transport Energy Demand Induced by Urban Accessibility}

Transport energy demand is typically derived from the total distance travelled by different motorised transport modes and the standardised energy consumption for each different mode (while taking into account the modal share of each city). This simple calculation already hints at the key components that impact the energy efficiency of urban transport systems: first, the travel intensity or total motorised kilometres required to ensure metropolitan-wide accessibility; second, the share of energy-efficient transport modes; and third, the energy demand of motorised vehicles in operation.

13 By assigning all the dominantly residential typologies to one of the five urban morphology samples we were assuming the areas to be purely residential. However, these areas include mix use building. Adding this extra population (corresponding to a jobs ratio) allows a compensation for the final calculation for a total residential energy per capita.

14 Source: authors and data from IEA [132]. 
Given this study's interest in the impact of urban form on resource consumption, it is above all the first element, the travel intensity of a metropolitan system, which is of interest here. At the same time, urban form is also a central enabler for more energy-efficient transport modes such as public transport, walking and cycling. Due to data limitations, we present a comparative analysis of metropolitan accessibility for only two of the case study cities, Kuwait and Hong Kong.

With regard to the (theoretical) travel intensity induced by each of the two cities' distribution of jobs and residents, a considerable difference can be observed (Table 5). With $17.8 \mathrm{~km}$, Kuwait's average distance between residential and job locations is 41 per cent higher than Hong Kong's average distance of $12.6 \mathrm{~km}$. While these findings may be in line with what one would expect given the efficiency of Hong Kong's urban form and transport systems, it is worth noting that these efficiencies are achieved in a considerably larger city fragmented by natural constraints, which tends to lead to longer commuting times and distances.

Table 5. Metropolitan accessibility for travel to work.

\begin{tabular}{ccccc}
\hline & Jobs & Population & Area [sqkm] & One-Way Commuting Distance [km] \\
\hline Kuwait & $1,703,145$ & $4,178,572$ & 852 & 17.8 \\
Hong Kong & $2,543,460$ & $7,305,700$ & 1109 & 12.6 \\
\hline
\end{tabular}

In terms of public transport accessibility, Kuwait and Hong Kong are similarly different (Figure 9). This can be illustrated by analysing the percentage of residents and employees who have access to public transport, using a threshold of 500-metre distance to the next public transport station or stop. The proportion of the population that can conveniently access a bus stop in Kuwait (as Kuwait does not have a rail-based public transport system) is 31 per cent, compared to 73 per cent in Hong Kong. In fact, 38 per cent of the population in Hong Kong lives within 500 metres of a rail station, providing the city with higher levels of access to rail alone compared to Kuwait's overall public transport (bus) access.

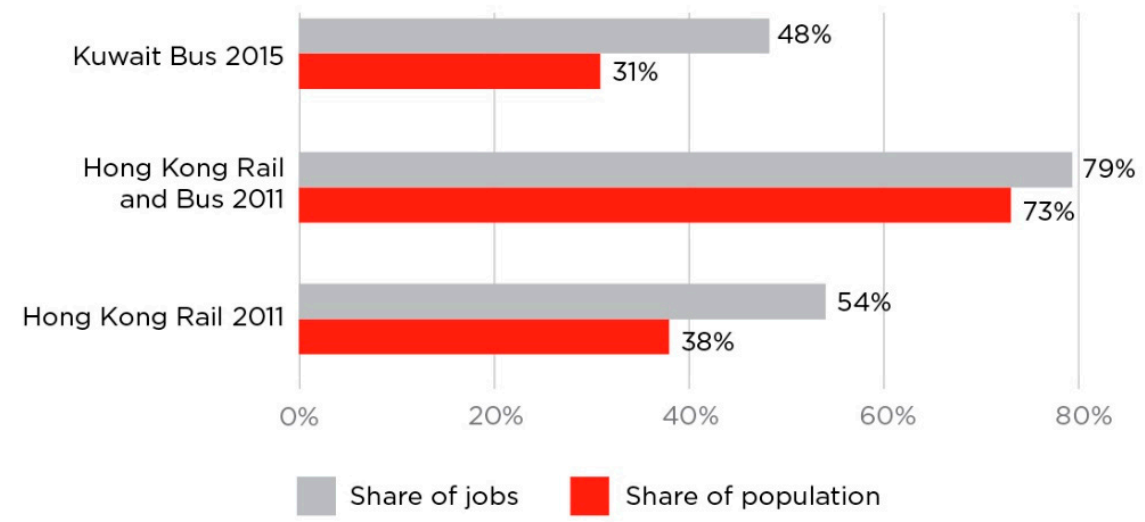

Figure 9. Residential and workplace accessibility to public transport.

Turning to workplace accessibility to public transport, which is higher in both cities, reveals convenient access for 48 per cent of all jobs in Kuwait and 79 per cent in Hong Kong. Again, the accessibility from jobs to rail alone in Hong Kong (54 per cent) is higher than Kuwait's overall job access to buses.

The commuting energy consumption in Kuwait and Hong Kong was calculated based on average distance to jobs, mode share and their standard energy consumption values from official statistics and scientific literature. The analysis is based on 261 working days per calendar year.

Table 6 presents mode share and standard energy consumption values in megajoules (MJ) per passenger kilometre for both metropolitans. Based on local statistics, this analysis also assumes that in Kuwait, 55 per cent of workers travel by car or taxi and only 39 per cent use buses for work travel. Similarly in Hong Kong, eight per cent of workers travel by car or taxi, 44.5 per cent travel by bus and 
35.9 per cent travel by rail. Literature on energy consumption in Asian cities, based on the research by Kenworthy $[135,136]$, states that, on average, car-based travel consumes approximately three to four times more energy than bus-based mobility and eleven times more energy than rail-based mobility. Based on actual mode share data from both cities, it is estimated that, for every passenger kilometre travelled, energy consumption in Kuwait is about $1.82 \mathrm{MJ}$, which is roughly 3.4 times higher than for Hong Kong (0.53 MJ).

Table 6. Mode share and standardised energy consumption in Kuwait and Hong Kong: MJ per passenger kilometre per day.

\begin{tabular}{cccccc}
\hline & \multicolumn{2}{c}{ Mode Share (per cent) } & \multicolumn{3}{c}{ Standardised Energy Consumption (MJ/passenger km) } \\
\hline Mode & Kuwait & Hong Kong & Kuwait & Hong Kong & Source \\
\hline Private car & 55 & 8 & 2.6 & 2.3 & Kenworthy \& Townsend (2011) \\
Buses & 39 & 45 & 0.7 & 0.5 & Kenworthy (2003) \\
Rail & 0 & 36 & N/A & 0.2 & Kenworthy (2008) \\
Weighted average & - & - & 1.8 & 0.5 & LSE Cities \\
\hline
\end{tabular}

Figure 10 presents the energy consumption based on the standardised energy demand per kilometre, and the annual commuting-related distances travelled. On average, in Kuwait, the (theoretical) annual energy demand for commuting is $15.8 \mathrm{GJ}$ per person, five times the amount of the commuting energy demand in Hong Kong (3.1 GJ). If all trips were made by car, annual commuting would consume 23.8 GJ per person in Kuwait and 15.3 GJ in Hong Kong. Similarly, bus-only commuting would require 6.9 GJ in Kuwait and 3.2 GJ in Hong Kong per commuter per year. Rail-only commuting in Hong Kong would be the most energy-efficient motorised mode, with 1.2 GJ per commuter per annum. This simple calculation suggests that lower levels of workplace accessibility and high car dependence play a central role in contributing to high transport energy demand in Kuwait as compared to Hong Kong. These differences are substantial and lead to an absolute annual energy consumption for travel to work of about 26,849 terajoules (TJ) in Kuwait metropolitan and only 7833 TJ in Hong Kong. Assuming that commuting-related travel typically only accounts for about 20 per cent of all urban mobility kilometres in a city, the total difference in transport energy demand between the two cities may be as high as 95,080 TJ. For comparison, an average nuclear power station with an installed capacity of $1000 \mathrm{KW}$ produces about 31,500 TJ of electricity per year. To meet Kuwait's high transport energy demand, the city requires the equivalent of three average nuclear power plants.

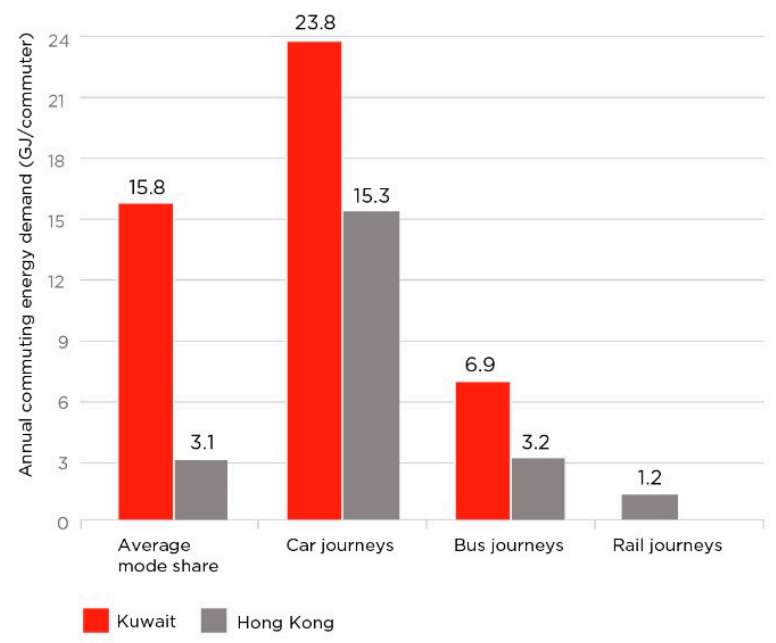

Figure 10. Daily per capita energy consumption for work journeys in Kuwait and Hong Kong.

To summarise, it is important to re-emphasise the considerable degree of evidence this study has presented on the strong relationships between urban form and energy demand. For both key 
aspects analysed here, the cooling and transport energy demand, factors related to urban form such as urban density, building density, distribution of functions and transport infrastructure were repeatedly found to be strong predictors for energy needs. In the context of cooling energy demand, the study established a theoretical factor of three between the most and least energy-efficient urban morphology within the same climate. The theoretical difference calculated here for transport energy demands is even more pronounced and calculations indicated a factor of five difference in transport energy needs as a result of the different spatial configurations of Hong Kong and Kuwait.

\section{Discussion}

Our analysis confirmed a range of established assumptions and generated several new findings. At the most generic level, the study is able to trace key relationships following the basic "resource urbanisms" logic across the wider spectrum of resource conditions, urban form at multiple scales, and resource consumption. Therefore, the study was able to demonstrate, at the scale of metropolitan development, the existence of the same resource logic which previous work investigated for urban sub-systems and the transport and building sectors [24-27]. These insights were established based on a mixed methods approach and, at a high level, confirmed a clear relationship between land scarcity, higher density developments and significantly lower building cooling and transport energy demand.

In terms of building on an established understanding of urban growth factors, this study confirmed that natural resources and, above all, land, as a scarce, non-tradable and non-substitutable natural resource, play an integral role in shaping urban form at the macro and micro scale. Unlike other natural resources, land area, with, by and large, locally fixed supply, is one of the most important variables explaining differences in city growth [137-144]. This finding is in line with numerous studies spanning different disciplinary perspectives on urban change [145-147].

More specific findings were established in relation to the impact of energy prices and oil endowments on urban form. This research finds that fuel prices are associated with periods of densification and de-densification in the case study cities. However, recorded relationships are generally more nuanced compared to the impact of land availability, and the recorded sample size did not allow for statistically credible generalisations. One explanation for a weaker correlation might be the fact that excess energy use for cooling can partly be compensated by higher efficiencies of equipment or energy performance of buildings. In Kuwait, Abu Dhabi, Singapore and Hong Kong, the established patterns suggest a possible correlation between fuel prices and densification patterns, with higher prices linked to more compact patterns of development. This aligns with studies that have explored how cheap oil prices can be associated with sprawling urban development $[31,44,148]$. Electricity prices may have a more indirect relationship as they increase. Recent price increases recorded in Abu Dhabi may render cooling energy costs for larger houses less affordable, thus reducing the demand for such housing typologies [149,150].

In terms of the variations of theoretical building cooling and transport energy demands between the case study cities, these were found to be significant and with factor differences of between three for cooling energy demand and five for transport energy demand. While broadly in line with related studies, modelling and empirical findings of actual energy consumption elsewhere, $[67,71,75,80,151,152]$ these differences are at the higher end of comparable studies and also reflect in Kuwait and Hong Kong the selection of two extremes of urban form. When exploring residential energy consumption at the metropolitan level, this research confirms the internationally established differences between Gulf and East Asian cities $[75,153,154]$. The research modelling produced a factor three difference between the most efficient city in terms of energy consumption per capita, Singapore $(9714 \mathrm{kWh} / \mathrm{pc})$ and Abu Dhabi, with $27,787 \mathrm{kWh} / \mathrm{pc}$. This compares as follows with the actual energy consumption differences: Singapore (1477 kWh/pc) and Abu Dhabi, with 24,576 kWh/pc [132].

We also identified a clear relationship between specific urban forms and energy consumption with the same broad pattern of more compact development, resulting in higher energy efficiency for building cooling and transport. This is once again in line with most previous research [71,75,152]. 
For cooling energy demand, the modelling confirmed a negative correlation with compact building morphologies, with higher densities and building heights resulting in lower energy demand. This has previously been confirmed by many studies on heat energy demand in buildings $[67,80,82,83]$.

Transport energy efficiency was found to similarly depend on urban form and above all the combination of density, diversity (mixed land use) and public transport infrastructure. Our theoretical calculations of the average distances between living and working areas in Kuwait and Hong Kong, alongside mode share considerations, translate to variations in transport energy demands, which broadly respond to field observations. Official statistics (2015), which include all types of transport activities (including non-passenger transport), present a factor of two difference [77]. When exploring differences in $\mathrm{CO}_{2}$ emissions from fuel combustion, a factor of four difference between these cities has been documented [132]. Broadly, the actual data correspond with the factor of five difference per capita demand identified in this paper, which only considers journeys to work and which is primarily based on the difference between more dispersed and functionally segregated Kuwait compared to compact and mixed use Hong Kong.

Given the above, our study also establishes a tentative conclusion that for the case of the selected higher-income case study cities, the identified resource constraints (above all land) in Hong Kong and Singapore have enabled better environmental sustainability outcomes at a metropolitan and housing typology scale.

\section{Conclusions}

Our paper is aligned with the growing number of studies that confirm that the shape and physical configuration of cities directly impacts on energy requirements and resource efficiency, making urban morphologies a critical factor for global sustainability, particularly as infrastructure investments result in considerable time lags and lock-in effects. It is also adding to a smaller amount of prior work that investigates and confirms the considerable degree to which resource conditions shape urban form in the first place.

For the latter, the use of a new urban growth metric, the urban living area (ULA), was particularly helpful for our analysis and emphasised the importance of introducing qualitative perspectives as part of quantitative remote sensing analysis. While increasingly sophisticated software and higher resolution photographic material will assist in a better differentiation between building typologies and urban infrastructures in the future, the available data for this analysis and particularly the historic datasets required complementary qualitative assessments of categorising land uses.

The methods developed for the comparison of cooling energy demands allow us to calculate a number of quantitative indicators for comparisons applicable to other cities and climatic regions. The use of semantic urban data models (CityGML) allows us to calculate indicators originating from the building scale, such as the surface-to-volume ratio at the scale of urban areas. Here, opportunities for future research exist in relation to the effect of urban heat islands (UHIs) on cooling energy demand in complex urban environments. Of further interest may be potential trade-offs between cooling and horizontal transport energy of vertical building typologies on the one hand and their embedded energy needs alongside energy consumption linked to the vertical movement of lifts on the other. The latter could build on initial findings by Murshed et al. [155].

Above all, this study implies that there are key opportunities for future research on the relationship between urban development and natural resources. Most importantly, the analysis can be expanded to also investigate water, food and other material resources and their impact on urban form. Given the overwhelming importance of land availability in this regard, future research could also bridge the extensive amount of existing work on land economics, tenure and real estate, and land as critical natural capital.

This paper also adds to a broader understanding of urban planning policies. In the cases of Singapore and Hong Kong, land constraints and population pressures are central to understanding the adoption of compact growth policies, whereas in the cases of Kuwait and Abu Dhabi, land 
availability and lower population levels are key in explaining the adoption of low-density housing welfare initiatives and car-centric city planning. The established urban metrics in this paper may allow us to classify urban space not only for comparative research but also for planning purposes [156].

While this research explores the influence of land and energy on urban form, it is important to emphasise that differences in the built environment across the four case study cities also need to be understood as a result of other critical factors. Aside from geographical factors and natural resource availability, differences in urban form between the GCC and East Asian case study cities are also the direct result of political-economy factors that have determined the nature of growth and urban development patterns. These patterns themselves are reflections of historical processes that have shaped city growth over time.

Author Contributions: Conceptualization P.R.; methodology P.R., A.G., M.A., A.K., S.M.M.; software M.A. and S.M.M.; validation, P.R., A.G., A.K.; formal analysis, P.R., A.G., M.A., F.S., A.K., S.M.M.; investigation, P.R., A.G., M.A., F.S., A.K., S.M.M.; resources, P.R., A.G.; data curation, A.G., M.A., S.M.M.; writing一original draft preparation, P.R., A.G., F.S.; writing—review and editing, P.R., A.G., M.A., F.S., A.K., S.M.M.; visualization, A.G., M.A.; supervision, P.R., A.K.; project administration, A.G.; funding acquisition, P.R. All authors have read and agreed to the published version of the manuscript.

Funding: This research was funded by the LSE Kuwait Programme/LSE Middle East Centre.

Acknowledgments: This paper is based on the Resource Urbanisms project that LSE Cities at the London School of Economics and Political Science led between 2015 and 2017. It was supported by the Kuwait Programme at the LSE Middle East Centre and the Kuwait Foundation for the Advancement of Sciences (KFAS). The authors would like to thank the project researchers Jenny McArthur, Sharifa Alshalfan, Peter Schwinger, Devisari Tunas, Christiane Lange, Clemence Montagne, Steffen Hertog, Jochen Wendel and Alice Duval as well as all experts and authorities for providing valuable inputs to this work.

Conflicts of Interest: The authors declare no conflict of interest. The funders had no role in the design of the study; in the collection, analyses, or interpretation of data; in the writing of the manuscript, or in the decision to publish the results.

\section{Appendix A}

Table A1. Mapping sources by data type.

\begin{tabular}{ccccc}
\hline Year & Kuwait & Abu Dhabi & Singapore & Hong Kong \\
\hline pre 1950s & 1931 & - & $1929 ; 1945$ & 1931 \\
$1950 \mathrm{~s}$ & 1951 & 1949 & 1954 & 1945 \\
$1960 \mathrm{~s}$ & 1963 & $1960 ; 1969$ & 1969 & - \\
$1970 \mathrm{~s}$ & 1977 & - & 1978 & 1971 \\
$1980 \mathrm{~s}$ & $1982 ; 1986$ & $1982 ; 1986$ & 1983 & 1981 \\
$1990 \mathrm{~s}$ & 1990 & 1990 & 1991 & 1992 \\
$2000 \mathrm{~s}$ & $2000 ; 2006$ & $2000 ; 2006$ & $2000 ; 2006$ & $2000 ; 2006$ \\
2010s & 2015 & 2015 & 2015 & 2015 \\
\hline Data type legend (colours): & Paper maps & Aerial photographs & Satellite images & N/A not available \\
\hline
\end{tabular}

Table A2. Quantitative review of academic urban form literature in relation to resource conditions and implications-results table.

\begin{tabular}{|c|c|c|c|c|}
\hline & Term 1 & Term 2 & Google Scholar & Web of Science \\
\hline \multicolumn{5}{|l|}{ Upstream } \\
\hline 1 & Urban form & Resource conditions & 90 & 0 \\
\hline 2 & & Energy price & 710 & 0 \\
\hline 3 & & Fuel price & 1220 & 3 \\
\hline 4 & & Road infrastructure & 4150 & 6 \\
\hline 5 & & Land availability & 1920 & 4 \\
\hline 6 & & Petrol affordability & 1 & 0 \\
\hline 7 & & Land scarcity & 690 & 1 \\
\hline 8 & & Land constraints & 293 & 0 \\
\hline
\end{tabular}


Table A2. Cont.

\begin{tabular}{|c|c|c|c|c|}
\hline & Term 1 & Term 2 & Google Scholar & Web of Science \\
\hline 9 & & Resource abundance & 80 & 0 \\
\hline 10 & & Oil based economy & 103 & 0 \\
\hline 11 & & Oil availability & 37 & 0 \\
\hline 12 & & Fuel affordability & 5 & 0 \\
\hline 13 & & Fuel costs & 1540 & 3 \\
\hline 14 & & Infrastructure investments & 3610 & 9 \\
\hline 15 & & Oil endowments & 1 & 0 \\
\hline Total results & & & 14,450 & 26 \\
\hline \multicolumn{5}{|l|}{ Downstream } \\
\hline 1 & Urban form & Energy consumption & 18,800 & 282 \\
\hline 2 & & Resource Impact & 285 & 1 \\
\hline 3 & & Carbon emissions & 7690 & 74 \\
\hline 4 & & Resource use & 4310 & 11 \\
\hline 5 & & Energy demand & 6100 & 60 \\
\hline 6 & & Environmental sustainability & 11,000 & 38 \\
\hline 7 & & Energy efficiency & 12,500 & 97 \\
\hline 8 & & Resource consumption & 3040 & 14 \\
\hline 9 & & Land consumption & 3110 & 16 \\
\hline 10 & & Oil consumption & 819 & 1 \\
\hline 11 & & Energy use & 13,900 & 162 \\
\hline 12 & & $\mathrm{CO}_{2}$ emissions & 6690 & 144 \\
\hline 13 & & Resource efficiency & 1930 & 5 \\
\hline Total results & & & 90,174 & 905 \\
\hline
\end{tabular}

\section{References}

1. Steemers, K. Urban Form and Energy Use. In Cities for the New Millennium; Spon Press: London, UK; New York, NY, USA, 2001; pp. 115-124. ISBN 978-0-415-23183-1.

2. Girardet, H. The Metabolism of Cities. In The Sustainable Urban Development Reader; Routledge: London, UK, 2004; pp. 125-132.

3. Kenworthy, J.R. The eco-city: Ten key transport and planning dimensions for sustainable city development. Environ. Urban. 2006, 18, 67-85. [CrossRef]

4. Newman, P. The environmental impact of cities. Environ. Urban. 2006, 18, 275-295. [CrossRef]

5. Swilling, M.; Robinson, B.; Marvin, S.; Hodson, M. City-Level Decoupling: Urban Resource Flows and the Governance of Infrastructure Transitions; A Report of the Working Group on Cities of the International Resource Panel; UNEP International Resource Panel: Paris, France, 2013.

6. Ahlfeldt, G.; Pietrostefani, E. Demystifying Compact Urban Growth: Evidence from 300 Studies from across the World; The New Climate Economy: London, UK; Washington, DC, USA, 2017; pp. 1-84.

7. Brenner, N. Debating planetary urbanization: For an engaged pluralism. Environ. Plan. D 2018, 36, 570-590. [CrossRef]

8. Ruddick, S.; Peake, L.; Tanyildiz, G.S.; Patrick, D. Planetary urbanization: An urban theory for our time? Environ. Plan. D 2017, 36, 387-404. [CrossRef]

9. DeLaurentis, D.; Callaway, R.K. “CAB” A System-of-Systems Perspective for Public Policy Decisions. Rev. Policy Res. 2004, 21, 829-837. [CrossRef]

10. Batty, M. Complexity in city systems: Understanding, evolution, and design. In A Planner's Encounter with Complexity; Routledge: London, UK; New York, NY, USA, 2010; ISBN 978-1-4094-0265-7.

11. Kasai, S.; Li, N.; Fang, D. A system-of-systems approach to understanding urbanization-state of the art and prospect. Smart Sustain. Built Environ. 2015, 4, 154-171. [CrossRef]

12. Derrible, S. Urban infrastructure is not a tree: Integrating and decentralizing urban infrastructure systems. Environ. Plan. B 2017, 44, 553-569. [CrossRef]

13. Breheny, M.J. (Ed.) Sustainable Development and Urban Form; London Pion Ltd.: London, UK, 1992; ISBN 978-0-85086-160-0. 
14. Jenks, M.; Williams, K. The Compact City: A Sustainable Urban Form? Burton, E., Ed.; Routledge: London, UK; New York, NY, USA, 1996; ISBN 978-0-419-21300-0.

15. Burton, E.; Jenks, M.; Williams, K.; Jenks, M.; Williams, K. Achieving Sustainable Urban Form; E \& FN Spon: London, UK, 2000; ISBN 978-0-203-82792-5.

16. Sorensen, A.; Okata, J. (Eds.) Megacities: Urban Form, Governance, and Sustainability; cSUR-UT Series: Library for Sustainable Urban Regeneration; Springer: Tokyo, Japan, 2011; ISBN 978-4-431-99266-0.

17. Silva, M.; Oliveira, V.; Leal, V. Urban Form and Energy Demand: A Review of Energy-relevant Urban Attributes. J. Plan. Lit. 2017, 32, 346-365. [CrossRef]

18. Creutzig, F.; Lohrey, S.; Bai, X.; Baklanov, A.; Dawson, R.; Dhakal, S.; Lamb, W.F.; McPhearson, T.; Minx, J.; Munoz, E.; et al. Upscaling urban data science for global climate solutions. Glob. Sustain. 2019, 2. [CrossRef]

19. Lobo, J.; Alberti, M.; Allen-Dumas, M.; Arcaute, E.; Barthelemy, M.; Bojorquez Tapia, L.A.; Brail, S.; Bettencourt, L.; Beukes, A.; Chen, W.-Q.; et al. Urban Science: Integrated Theory from the First Cities to Sustainable Metropolises; Social Science Research Network: Rochester, NY, USA, 2020.

20. Anderson, W.P.; Kanaroglou, P.S.; Miller, E.J. Urban Form, Energy and the Environment: A Review of Issues, Evidence and Policy. Urban Stud. 1996, 33, 7-35. [CrossRef]

21. Cervero, R.; Kockelman, K. Travel demand and the 3Ds: Density, diversity, and design. Transp. Res. Part D 1997, 2, 199-219. [CrossRef]

22. Tsai, Y.-H. Quantifying Urban Form: Compactness versus "Sprawl". Urban Stud. 2005, 42, 141-161. [CrossRef]

23. Alberti, M. Modeling the Urban Ecosystem: A Conceptual Framework. Environ. Plan. B 1999, 26, 605-629. [CrossRef]

24. Sterner, T. Fuel taxes: An important instrument for climate policy. Energy Policy 2007, 35, 3194-3202. [CrossRef]

25. Davis, L.W.; Kilian, L. Estimating the effect of a gasoline tax on carbon emissions. J. Appl. Econom. 2011, 26, 1187-1214. [CrossRef]

26. Economidou, M.; Todeschi, V.; Bertoldi, P.; D'Agostino, D.; Zangheri, P.; Castellazzi, L. Review of 50 years of EU energy efficiency policies for buildings. Energy Build. 2020, 225, 110322. [CrossRef]

27. Nässén, J.; Holmberg, J. Energy efficiency-a forgotten goal in the Swedish building sector? Energy Policy 2005, 33, 1037-1051. [CrossRef]

28. Carlino, G.A. Three Keys to the City: Resources, Agglomeration Economies, and Sorting. Bus. Rev. 2011, Q3, $1-13$.

29. Kostof, S. The City Shaped: Urban Patterns and Meanings through History; Little, Brown and Company: New York, NY, USA, 1991; ISBN 978-0-8212-1867-9.

30. Rappaport, J.; Sachs, J.D. The United States as a Coastal Nation. J. Econ. Growth 2003, 8, 5-46. [CrossRef]

31. Creutzig, F. How fuel prices determine public transport infrastructure, modal shares and urban form. Urban Clim. 2014, 10, 63-76. [CrossRef]

32. Freeman, O.W. Natural Resources and Urban Development. Ann. Am. Acad. Political Soc. Sci. 1945, 242, 30-45. [CrossRef]

33. Phang, S.Y. The Singapore Model of Housing and the Welfare State. In Housing and the New Welfare State: Perspectives from East Asia and Europe; Groves, R., Murie, A., Watson, C.J., Eds.; Ashgate: Aldershot, UK, 2007; pp. $15-44$.

34. Huat, C.B. Singapore as Model: Planning Innovations, Knowledge Experts. In Worlding Cities: Asian Experiments and the Art of Being Global; Roy, A., Ong, A., Eds.; Wiley-Blackwell: Oxford, UK, 2011; pp. 27-54. ISBN 978-1-4443-4680-0.

35. Gollin, D.; Jedwab, R.; Vollrath, D. Urbanization with and without industrialization. J. Econ. Growth 2016, 21, 35-70. [CrossRef]

36. Jedwab, R. Urbanization without Structural Transformation: Evidence from Consumption Cities in Africa; George Washington University: Washington, DC, USA, 2013.

37. Acemoglu, D.; Johnson, S.; Robinson, J.A. Reversal of Fortune: Geography and Institutions in the Making of the Modern World Income Distribution. Q. J. Econ. 2002, 117, 1231-1294. [CrossRef]

38. Davis, J.C.; Henderson, J.V. Evidence on the political economy of the urbanization process. J. Urban Econ. 2003, 53, 98-125. [CrossRef]

39. Fay, M.; Opal, C. Urbanization without Growth: A Not-So-Uncommon Phenomenon; Policy Research Working Papers; The World Bank: Washington, DC, USA, 2000.

40. Bertinelli, L.; Black, D. Urbanization and growth. J. Urban Econ. 2004, 56, 80-96. [CrossRef] 
41. Jedwab, R.; Vollrath, D. Urbanization without growth in historical perspective. Explor. Econ. Hist. 2015, 58, 1-21. [CrossRef]

42. Glaeser, E.L. A World of Cities: The Causes and Consequences of Urbanization in Poorer Countries. J. Eur. Econ. Assoc. 2014, 12, 1154-1199. [CrossRef]

43. Walton, J. Urban Sociology: The Contribution and Limits of Political Economy. Annu. Rev. Sociol. 1993, 19, 301-320. [CrossRef]

44. Gilbert, A.; Healey, P. The Political Economy of Land: The State and Urban Development in Venezuela; Gower Publishing Company: Aldershot, UK, 1985.

45. Henderson, J.V. Urbanization and Growth; Brown University: Providence, RI, USA, 2004.

46. Pistor, K.; Schutter, O.D. (Eds.) Governing Access to Essential Resources; Columbia University Press: New York, NY, USA, 2015; ISBN 978-0-231-54076-6.

47. Angel, S.; Parent, J.; Civco, D.L.; Blei, A.; Potere, D. The dimensions of global urban expansion: Estimates and projections for all countries, 2000-2050. Prog. Plan. 2011, 75, 53-107. [CrossRef]

48. Seto, K.C.; Fragkias, M.; Güneralp, B.; Reilly, M.K. A Meta-Analysis of Global Urban Land Expansion. PLoS ONE 2011, 6, e23777. [CrossRef]

49. Colsaet, A.; Laurans, Y.; Levrel, H. What drives land take and urban land expansion? A systematic review. Land Use Policy 2018, 79, 339-349. [CrossRef]

50. Zhang, X.Q. High-Rise and High-Density Compact Urban Form: The Development of Hong Kong. In Compact Cities: Sustainable Urban Forms for Developing Countries; Jenks, M., Burgess, R., Eds.; Spon Press: London, UK; New York, NY, USA, 2000; ISBN 978-0-419-25130-9.

51. Addae-Dapaah, K. Utilization of urban residential land: A case study of Singapore. Cities 1999, 16, 93-101. [CrossRef]

52. Fuccaro, N. Introduction Histories of Oil and Urban Modernity in the Middle East. Comp. Stud. South Asia Afr. Middle East 2013, 33, 1-6. [CrossRef]

53. Al-Nakib, F. Kuwait's Modern Spectacle Oil Wealth and the Making of a New Capital City, 1950-1990. Comp. Stud. South Asia Afr. Middle East 2013, 33, 7-25. [CrossRef]

54. Bet-Shlimon, A. The Politics and Ideology of Urban Development in Iraq's Oil City Kirkuk, 1946-1958. Comp. Stud. South Asia Afr. Middle East 2013, 33, 26-40. [CrossRef]

55. Alissa, R. The Oil Town of Ahmadi since 1946 From Colonial Town to Nostalgic City. Comp. Stud. South Asia Afr. Middle East 2013, 33, 41-58. [CrossRef]

56. Damluji, M. The Oil City in Focus The Cinematic Spaces of Abadan in the Anglo-Iranian Oil Company's Persian Story. Comp. Stud. South Asia Afr. Middle East 2013, 33, 75-88. [CrossRef]

57. Lawless, R.I.; Seccombe, I.J. Impact of the Oil Industry on Urbanization in the Persian Gulf Region. In Urban Development in the Muslim World; Amirahmadi, H., Shakhs, S.S.E., Eds.; Routledge: Abingdon, UK; New York, NY, USA, 1993; pp. 183-212.

58. Crinson, M. Abadan: Planning and architecture under the Anglo-Iranian Oil Company. Plan. Perspect. 1997, 12, 341-359. [CrossRef]

59. Fuccaro, N. Histories of City and State in the Persian Gulf: Manama since 1800; Cambridge University Press: Cambridge, MA, USA, 2009.

60. Al-Nakib, F. Kuwait Transformed: A History of Oil and Urban Life; Stanford University Press: Stanford, CA, USA, 2016.

61. Fuccaro, N. Shaping the Urban Life of Oil in Bahrain Consumerism, Leisure, and Public Communication in Manama and in the Oil Camps, 1932-1960s. Comp. Stud. South Asia Afr. Middle East 2013, 33, 59-74. [CrossRef]

62. Baum-Snow, N. Did Highways Cause Suburbanization? Q. J. Econ. 2007, 122, 775-805. [CrossRef]

63. Henderson, J.V. Cities and Development. J. Reg. Sci. 2010, 50, 515-540. [CrossRef]

64. Baum-Snow, N.; Brandt, L.; Henderson, J.V.; Turner, M.A.; Zhang, Q. Roads, Railroads, and Decentralization of Chinese Cities. Rev. Econ. Stat. 2017, 99, 435-448. [CrossRef]

65. IPCC. Climate Change 2014: Mitigation of Climate Change. Contribution of Working Group III to the Fifth Assessment Report of the Intergovernmental Panel on Climate Change (IPCC); Cambridge University Press: Cambridge, UK; New York, NY, USA, 2014; p. 927.

66. Ewing, R.; Cervero, R. Travel and the Built Environment. J. Am. Plan. Assoc. 2010, 76, 265-294. [CrossRef]

67. Rode, P.; Keim, C.; Robazza, G.; Viejo, P.; Schofield, J. Cities and Energy: Urban Morphology and Residential Heat-Energy Demand. Environ. Plan. B 2014, 41, 138-162. [CrossRef] 
68. Rode, P. Cities and the New Climate Economy: The Role of Transport and Urban Form; Abu Dhabi Urban Planning Council Lecture: Abu Dhabi, UAE, 2014.

69. GCEC. Better Growth, Better Climate: The New Climate Economy Report; The Global Commission on the Economy and Climate: Washington, DC, USA, 2014; p. 72.

70. OECD. Compact City Policies: A Comparative Assessment; Organisation for Economic Co-Operation and Development (OECD): Paris, France, 2012.

71. Lefèvre, B. Urban Transport Energy Consumption: Determinants and Strategies for its Reduction. An analysis of the literature. SAPI EN. S. Surv. Perspect. Integr. Environ. Soc. 2009, 2, 1-17.

72. Papa, R.; Gargiulo, C.; Zucaro, F.; Angiello, G.; Carpentieri, G. Urban Energy Consumptions: Its Determinants and Future Research. WIT Trans. Ecol. Environ. 2014, 191, 561-570. [CrossRef]

73. Steemers, K. Energy and the city: Density, buildings and transport. Energy Build. 2003, 35, 3-14. [CrossRef]

74. Madlener, R.; Sunak, Y. Impacts of urbanization on urban structures and energy demand: What can we learn for urban energy planning and urbanization management? Sustain. Cities Soc. 2011, 1, 45-53. [CrossRef]

75. Güneralp, B.; Zhou, Y.; Ürge-Vorsatz, D.; Gupta, M.; Yu, S.; Patel, P.L.; Fragkias, M.; Li, X.; Seto, K.C. Global scenarios of urban density and its impacts on building energy use through 2050. Proc. Natl. Acad. Sci. USA 2017, 201606035. [CrossRef] [PubMed]

76. Kenworthy, J.R.; Newman, P.W.G. Cities and transport energy: Lessons from a global survey. Ekistics 1990, 57, 258-268.

77. IEA International Energy Agency Statistics Data Browser. Available online: https://www.iea.org/statistics/ ?country=WORLD\&year=2015\&category=Energy $\% 20$ consumption\&indicator $=$ TFCShareBySector\& mode $=$ table $\&$ dataTable $=$ BALANCES (accessed on 30 April 2019).

78. IEA. Key World Energy Statistics; International Energy Agency: Paris, France, 2016.

79. Baker, N.; Steemers, K. Energy and Environment in Architecture: A Technical Design Guide; E \& FN Spon: London, UK, 2000; ISBN 978-0-419-22770-0.

80. Ratti, C.; Baker, N.; Steemers, K. Energy consumption and urban texture. Energy Build. 2005, 37, 762-776. [CrossRef]

81. Yannas, S. Solar Energy and Housing Design; Architectural Association Publications: London, UK, 1993; ISBN 978-1-870890-45-8.

82. Vartholomaios, A. A parametric sensitivity analysis of the influence of urban form on domestic energy consumption for heating and cooling in a Mediterranean city. Sustain. Cities Soc. 2017, 28, 135-145. [CrossRef]

83. Zhang, J.; Xu, L.; Shabunko, V.; Tay, S.E.R.; Sun, H.; Lau, S.S.Y.; Reindl, T. Impact of urban block typology on building solar potential and energy use efficiency in tropical high-density city. Appl. Energy 2019, 240, 513-533. [CrossRef]

84. Smith, W.S. Mass Transport for High-Rise High-Density Living. J. Transp. Eng. 1984, 110, 521-535. [CrossRef]

85. Holtzclaw, J. Smart Growth-As Seen From the Air Convenient Neighborhood, Skip the Car. In Proceedings of the Air and Waste Management Association's 93rd Annual Meeting and Exhibition, Salt Lake City, UT, USA, 23 June 2000.

86. Ewing, R.; Rong, F. The impact of urban form on U.S. residential energy use. Hous. Policy Debate 2008, 19, 1-30. [CrossRef]

87. Handy, S.; Cao, X.; Mokhtarian, P.L. Self-Selection in the Relationship between the Built Environment and Walking: Empirical Evidence from Northern California. J. Am. Plan. Assoc. 2006, 72, 55-74. [CrossRef]

88. Zhang, M. Travel Choice with No Alternative: Can Land Use Reduce Automobile Dependence? J. Plan. Educ. Res. 2006, 25, 311-326. [CrossRef]

89. Zegras, C. The Built Environment and Motor Vehicle Ownership and Use: Evidence from Santiago de Chile. Urban Stud. 2010, 47, 1793-1817. [CrossRef]

90. Zhao, P. Car use, commuting and urban form in a rapidly growing city: Evidence from Beijing. Transp. Plan. Technol. 2011, 34, 509-527. [CrossRef]

91. Newman, P.; Kenworthy, J.R. Evaluating the Transport Sector's Contribution to Greenhouse Gas Emissions and Energy Consumption. In Technologies for Climate Change Mitigation: Transport Sector; Salter, R., Dhar, S., Newman, P., Eds.; TNA Guidebook Series, UNEP \& DTU; Magnum Custom Publishing: New Delhi, India, 2011; p. 250.

92. Banister, D.; Watson, S.; Wood, C. Sustainable Cities: Transport, Energy, and Urban Form. Environ. Plan. B 1997, 24, 125-143. [CrossRef] 
93. Mogridge, M.J.H. Transport, Land Use and Energy Interaction. Urban Stud. 1985, 22, 481-492. [CrossRef]

94. Baum-Snow, N.; Turner, M. Transport Infrastructure and the Decentralization of Cities in the People's Republic of China. Asian Dev. Rev. 2017, 34, 25-50. [CrossRef] [PubMed]

95. Dhakal, S. Urban energy use and carbon emissions from cities in China and policy implications. Energy Policy 2009, 37, 4208-4219. [CrossRef]

96. Agranoff, R.; Radin, B. The comparative case study approach in public administration. Res. Public Adm. 1991, 1, 203-231.

97. Yin, R.K. Case Study Research: Design and Methods; SAGE Publications: London, UK, 2013; ISBN 978-1-4833-0200-3.

98. Wendel, J.; Simons, A.; Nichersu, A.; Murshed, S.M. Rapid development of semantic 3D city models for urban energy analysis based on free and open data sources and software. In Proceedings of the ACM Urban GIS; UrbanGIS'17, Redondo Beach, CA, USA, 7-10 November 2017; p. 15.

99. Angel, S.; Parent, J.; Civco, D.L.; Blei, A.M. Atlas of Urban Expansion; Lincoln Institute of Land Policy: Cambridge, MA, USA, 2012.

100. ISO. Energy Performance of Buildings-Calculation of Energy Use for Space Heating and Cooling; ISO 13790:2008; ISO/TC 163/SC 2 Calculation Methods: Geneva, Switzerland, 2008; p. 162.

101. Kristensen, M.H.; Petersen, S. Choosing the appropriate sensitivity analysis method for building energy model-based investigations. Energy Build. 2016, 130, 166-176. [CrossRef]

102. Corrado, V.; Fabrizio, E. Assessment of building cooling energy need through a quasi-steady state model: Simplified correlation for gain-loss mismatch. Energy Build. 2007, 39, 569-579. [CrossRef]

103. Gröger, G.; Kolbe, T.; Nagel, C.; Häfele, K.-H. OGC City Geography Markup Language (Citygml) Encoding Standard 2.0.0; Open Geospatial Consortium: Wayland, MA, USA, 2012; p. 344.

104. Chalal, M.L.; Benachir, M.; White, M.; Shrahily, R. Energy planning and forecasting approaches for supporting physical improvement strategies in the building sector: A review. Renew. Sustain. Energy Rev. 2016, 64, 761-776. [CrossRef]

105. Koch, E.A. Continuous Simulation for Urban Energy Planning Based on a Non-Linear Data-Driven Modelling Approach. Ph.D. Thesis, Karlsruher Instituts für Technologie, Karlsruhe, Germany, 2016. [CrossRef]

106. Eicker, U.; Nouvel, R.; Schulte, C.; Schumacher, J.; Coors, V. 3D Stadtmodelle für die Wärmebedarfberechnung. In Proceedings of the Fourth German-Austrian IBPSA Conference; IBPSA: Berlin, Germany, 2012.

107. Nouvel, R.; Mastrucci, A.; Leopold, U.; Baume, O.; Coors, V.; Eicker, U. Combining GIS-based statistical and engineering urban heat consumption models: Towards a new framework for multi-scale policy support. Energy Build. 2015, 107, 204-212. [CrossRef]

108. Murshed, S.M.; Picard, S.; Koch, A. CityBEM: An Open Source Implementation and Validation of Monthly Heating and Cooling Energy Needs for 3D Buildings in Cities. ISPRS Ann. Photogramm. Remote Sens. Spat. Inf. Sci. 2017, IV-4/W5, 83-90. [CrossRef]

109. Murshed, S.M.; Picard, S.; Koch, A. Modelling, Validation and Quantification of Climate and Other Sensitivities of Building Energy Model on 3D City Models. ISPRS Int. J. Geo-Inf. 2018, 7, 447. [CrossRef]

110. Murshed, S.M.; Lindsay, A.; Picard, S.; Simons, A. PLANTING: Computing High Spatio-Temporal Resolutions of Photovoltaic Potential of 3D City Models. In Geospatial Technologies for All, Lecture Notes in Geoinformation and Cartography; Mansourian, A., Pilesjö, P., Harrie, L., van Lammere, R., Eds.; Springer International Publishing AG: Cham, Switzerland, 2018; in press.

111. TUM; virtualcitySYSTEMS; M.O.S.S. 3DCityDB Database-Homepage. Available online: https://www. 3dcitydb.org/3dcitydb/ (accessed on 23 October 2020).

112. PyDev. Available online: https://www.pydev.org/ (accessed on 23 October 2020).

113. IAI-Webmaster FZKViewer. Available online: https://www.iai.kit.edu/1302.php (accessed on 23 October 2020).

114. García-Ayllón, S. Retro-diagnosis methodology for land consumption analysis towards sustainable future scenarios: Application to a mediterranean coastal area. J. Clean. Prod. 2018, 195, 1408-1421. [CrossRef]

115. García-Nieto, A.P.; Geijzendorffer, I.R.; Baró, F.; Roche, P.K.; Bondeau, A.; Cramer, W. Impacts of urbanization around Mediterranean cities: Changes in ecosystem service supply. Ecol. Indic. 2018, 91, 589-606. [CrossRef]

116. Yiran, G.A.B.; Ablo, A.D.; Asem, F.E. Urbanisation and domestic energy trends: Analysis of household energy consumption patterns in relation to land-use change in peri-urban Accra, Ghana. Land Use Policy 2020, 99, 105047. [CrossRef]

117. SCAD. Abu Dhabi Statistical Yearbook; Statistics Centre: Abu Dhabi, UAE, 2016. 
118. CSD. Hong Kong Annual Digest of Statistics; Census and Statistics Department: Hong Kong, China, 2016; p. 514.

119. DSS. Population Trends; Department of Statistics Singapore: Singapore, 2017.

120. CSB. Statistical Abstract in 25 Years; Central Statistical Bureau: Kuwait City, Kuwait, 1990.

121. PACI. The Public Authority for Civil Information. Available online: https://www.paci.gov.kw/Default.aspx (accessed on 1 January 2016).

122. World Bank World Development Indicators (WDI)|Data Catalog. Available online: https://datacatalog. worldbank.org/dataset/world-development-indicators (accessed on 20 October 2017).

123. DSS. M890151-Land Area (as at December), Annual; Department of Statistics Singapore: Singapore, 2017.

124. Hong Kong Lands Department Reclamation Area (Since 1887). Available online: http://www.landsd.gov.hk/ mapping/en/publications/reclamation.htm (accessed on 12 October 2016).

125. Ministry of National Development. A High Quality Environment for All Singaporeans: Land Use Plan to Support Singapore's Future Population; Ministry of National Development: Singapore, 2013.

126. Rowe, P.G. East Asia Modern: Shaping the Contemporary City; Reaktion Books: London, UK, 2005; ISBN 978-1-86189-536-3.

127. EMA. Singapore Energy Statistics; Energy Market Authority: Singapore, 2015.

128. UN-Habitat; NYU; Lincoln Institute Atlas of Urban Expansion-Data. Available online: http:// atlasofurbanexpansion.org/data (accessed on 23 October 2020).

129. World Bank Energy Use (kg of Oil Equivalent Per Capita)\Textbar Data. Available online: https://data. worldbank.org/indicator/EG.USE.PCAP.KG.OE (accessed on 29 October 2017).

130. Lincoln Institute of Land and Policy; NYU; UN-Habitat Atlas of Urban Expansion-Cities. Available online: http://www.atlasofurbanexpansion.org/data (accessed on 25 July 2019).

131. Al-Mutairi, H.; Dewsbury, J.; Lane-Serff, G.F. Energy and the implication of residential cooling in hot climates: Case study for developing effective solution for residential cooling demand in Kuwait. In Proceedings of the WIT Transactions on Ecology and the Environment; WIT Press: Southampton, UK, 2011; Volume 150, pp. 1-12.

132. IEA. Key World Energy Statistics; International Energy Agency (IEA): Paris, France, 2015.

133. AboulNaga, M.M.; Elsheshtawy, Y.H. Environmental sustainability assessment of buildings in hot climates: The case of the UAE. Renew. Energy 2001, 24, 553-563. [CrossRef]

134. IEA Energy Statistics. Available online: https://www.iea.org/statistics/statisticssearch/ (accessed on 9 October 2017).

135. Kenworthy, J.R. Transport energy use and greenhouse gases in urban passenger transport systems: A study of 84 global cities. In Proceedings of the International Sustainability Conference, Fremantle, Australia, 17-19 September 2003; pp. 1-28.

136. Kenworthy, J.R. Energy Use and $\mathrm{CO}_{2}$ Production in the Urban Passenger Transport Systems of 84 International Cities: Findings and Policy Implications. In Urban Energy Transition: From Fossil Fuels to Renewable Power; Droege, P., Ed.; Elsevier: Oxford, UK, 2008.

137. OECD. Rethinking Urban Sprawl: Moving towards Sustainable Cities | en | OECD; OECD Publishing: Paris, France, 2018.

138. Oueslati, W.; Alvanides, S.; Garrod, G. Determinants of urban sprawl in European cities. Urban Stud. 2015, 52, 1594-1614. [CrossRef] [PubMed]

139. Sudhira, H.S.; Ramachandra, T.V.; Jagadish, K.S. Urban sprawl: Metrics, dynamics and modelling using GIS. Int. J. Appl. Earth Obs. Geoinf. 2004, 5, 29-39. [CrossRef]

140. Gennaio, M.-P.; Hersperger, A.M.; Bürgi, M. Containing urban sprawl-Evaluating effectiveness of urban growth boundaries set by the Swiss Land Use Plan. Land Use Policy 2009, 26, 224-232. [CrossRef]

141. Burgess, R.; Jenks, M. (Eds.) Compact Cities: Sustainable Urban Forms for Developing Countries; Spon Press: London, UK; New York, NY, USA, 2000; ISBN 978-1-135-80389-6.

142. Fenjie, L.; Ming, G. Research on the Impact of Land Supply on Urban Growth in China. CNKI 2009, 6, 83-87.

143. Capozza, D.R.; Helsley, R.W. The fundamentals of land prices and urban growth. J. Urban Econ. 1989, 26, 295-306. [CrossRef]

144. Drabkin, H.D. Land Policy and Urban Growth; Urban and Regional Planning Series; Pergamon Press: Oxford, UK, 1977; Volume 16, ISBN 978-0-08-020401-7.

145. Buxton, M.; Taylor, E. Urban Land Supply, Governance and the Pricing of Land. Urban Policy Res. 2010, 29, 5-22. [CrossRef] 
146. Rose, L.A. Urban land supply: Natural and contrived restrictions. J. Urban Econ. 1989, 25, 325-345. [CrossRef]

147. El Araby, M.M. The role of the state in managing urban land supply and prices in Egypt. Habitat Int. 2003, 27, 429-458. [CrossRef]

148. Haas, T.; Olsson, K. Emergent Urbanism: Urban Planning E Design in Times of Structural and Systemic Change; Routledge: London, UK; New York, NY, USA, 2016; ISBN 978-1-317-14485-4.

149. Staff Report Abu Dhabi Raises Water, Electricity Tariffs. Available online: https://gulfnews.com/business/ energy/abu-dhabi-raises-water-electricity-tariffs-1.1647201 (accessed on 23 October 2020).

150. Krane, J. Reforming end-user energy prices could rationalize GCC energy demand. Oxf. Energy Forum 2015, $102,38-41$.

151. Resch, E.; Bohne, R.A.; Kvamsdal, T.; Lohne, J. Impact of Urban Density and Building Height on Energy Use in Cities. Energy Procedia 2016, 96, 800-814. [CrossRef]

152. Newman, P.; Kenworthy, J. Sustainability and Cities: Overcoming Automobile Dependence; Island Press: Washington, DC, USA, 1999; ISBN 978-1-55963-660-5.

153. Chen, T.-L.; Chiu, H.-W.; Lin, Y.-F. How do East and Southeast Asian Cities Differ from Western Cities? A Systematic Review of the Urban Form Characteristics. Sustainability 2020, 12, 2423. [CrossRef]

154. Nathaniel, S.; Anyanwu, O.; Shah, M. Renewable energy, urbanization, and ecological footprint in the Middle East and North Africa region. Environ. Sci. Pollut. Res. 2020, 27, 14601-14613. [CrossRef]

155. Murshed, S.; Duval, A.; Koch, A.; Rode, P. Impact of Urban Morphology on Energy Consumption of Vertical Mobility in Asian Cities-A Comparative Analysis with 3D City Models. Urban Sci. 2018, 3, 4. [CrossRef]

156. Hegger, M.; Dettmar, J. Energetische Stadtraumtypen: Strukturelle und Energetische Kennwerte von Stadträumen; Fraunhofer IRB Verlag: Stuttgart, Gremany, 2014; ISBN 978-3-8167-9292-5.

Publisher's Note: MDPI stays neutral with regard to jurisdictional claims in published maps and institutional affiliations. 